\title{
THE ROLE OF FORMATE IN COMBATTING OXIDATIVE STRESS
}

By

Sean C. Thomas

Thesis submitted in partial fulfillment of the requirement for the degree of Master of Science (M.Sc.) in Biology

\author{
Faculty of Graduate Studies \\ Laurentian University \\ Sudbury, Ontario, Canada
}

(C) Sean C. Thomas, 2016 


\section{THESIS DEFENCE COMMITTEE/COMITÉ DE SOUTENANCEGE DE THÈSE Laurentian Université/Université Laurentienne \\ Faculty of Graduate Studies/Faculté des études supérieures}

Title of Thesis

Titre de la thèse

Name of Candidate

Nom du candidat

Degree

Diplôme

Department/Program

Département/Programme
THE ROLE OF FORMATE IN COMBATTING OXIDATIVE STRESS

Thomas, Sean Crispin

Master of Science

Biology

Date of Defence

Date de la soutenance March 18, 2016

\section{APPROVED/APPROUVÉ}

Thesis Examiners/Examinateurs de thèse:

Dr. A Omri

(Supervisor/Directeur(trice) de thèse)

Dr. Jean-Francois Robitaille

(Committee member/Membre du comité)

Dr. Kabwe NKongolo

(Committee member/Membre du comité)

Dr. Mongi Benjeddou

(External Examiner/Examinateur externe)

Approved for the Faculty of Graduate Studies Approuvé pour la Faculté des études supérieures Dr. David Lesbarrères

Monsieur David Lesbarrères

Dean, Faculty of Graduate Studies

Doyen, Faculté des études supérieures

\section{ACCESSIBILITY CLAUSE AND PERMISSION TO USE}

I, Sean Crispin Thomas, hereby grant to Laurentian University and/or its agents the non-exclusive license to archive and make accessible my thesis, dissertation, or project report in whole or in part in all forms of media, now or for the duration of my copyright ownership. I retain all other ownership rights to the copyright of the thesis, dissertation or project report. I also reserve the right to use in future works (such as articles or books) all or part of this thesis, dissertation, or project report. I further agree that permission for copying of this thesis in any manner, in whole or in part, for scholarly purposes may be granted by the professor or professors who supervised my thesis work or, in their absence, by the Head of the Department in which my thesis work was done. It is understood that any copying or publication or use of this thesis or parts thereof for financial gain shall not be allowed without my written permission. It is also understood that this copy is being made available in this form by the authority of the copyright owner solely for the purpose of private study and research and may not be copied or reproduced except as permitted by the copyright laws without written authority from the copyright owner. 


\begin{abstract}
As all aerobic organisms are exposed to oxidative stress, they are known to devise intricate mechanisms to counter reactive oxygen species (ROS). Metabolic networks contributing to the production of ketoacids are prominent in alleviating the oxidative burden. When glyoxylate detoxifies ROS, formate is the principal by-product generated. In this study the contribution of formate in enabling the survival of the microbe Pseudomonas fluorescens challenged by hydrogen peroxide $\left(\mathrm{H}_{2} \mathrm{O}_{2}\right)$ has been elucidated. When grown in the presence of $\mathrm{H}_{2} \mathrm{O}_{2}$ (stressed culture), the levels of formate were higher in the spent fluid and the soluble cell-free extracts compared to the controls. Formate was subsequently utilized as a reducing factor to produce NADPH and succinate. The former is mediated by formate dehydrogenase (FDH-NADP), whose activity was enhanced in the stressed cells. Fumarate reductase (FRD) that catalyzes the conversion of fumarate into succinate was also markedly increased in the stressed cells. Metabolic adaptation is a pivotal tool in combatting oxidative stress. Formate, a by-product of glyoxylate- mediated detoxification of ROS is recuperated as a potent reductive fuel. It is becoming quite evident that this simple metabolite has other biological roles that have not been fully appreciated.
\end{abstract}

Keywords: Formate metabolism, Pseudomonas fluorescens, ketoacids, glyoxylate, Formate dehydrogenase, Fumarate reductase- formate dependent, Isocitrate lyase. 


\section{Acknowledgments}

This thesis would have been impossible without the immense support of friends colleagues and mentors, and for it, there are several people to whom I owe eternal gratitude for their help and support. First and foremost, I wish to thank Dr. Appanna, whose guidance and mentorship have inspired me to always keep moving forward in the quest for knowledge and self-development. I also wish to thank Dr. Omri without whom this thesis would never be possible. I am very grateful for your support and advice which have helped shape it the way it is currently. Also I wish to thank Dr. Nkongolo and Dr. Robitaille, my committee members. Besides the guidance and help with the project, for taking the time to carefully look over all the details and providing invaluable feedback about my research, that helped shape and improve it, thank you very much. For making this an incredible learning experience and all the help and guidance in understanding the work, I am truly grateful.

To all my professors here at Laurentian, I'd like to say heartfelt thanks for taking the time to train our minds. From Paul Guerin and Francois Brunet to Bernie Shami and Peiter Waern, I am grateful to all the T.A.s who helped me hone my research skills. To Christopher Auger, for being a phenomenal lab manager and all his assistance and for his general friendship, I shall be forever indebted. To Azhar Alhasawi, for 'ALWAYS' being there to help with my experiments and ideas, I am very grateful. Special thanks to Sungwon Han, for bringing starcraft to the lab for those dreary days when experiments sapped the 
energy out of me and now when life does the same. Forever I shall remain grateful to Zachary Castonguay whose assistance during my undergrad has been critical to making any and all of this possible. I also wish to thank Joseph Lemire, Adam Bignucolo and Varun Appanna for their assistance with everything.

On a more personal note, I owe my deepest gratitude to my grandparents, my entire family and especially my parents, who have sacrificed a lot for my brother and me, and whom I love more than anything in this world. I would also like to thank my brother because if I were Fred, he'd be my George and I really can't imagine what I would have done without him. I also feel greatly obliged to thank all of the teachers who've ever taught me, from Mrs. Weatherylle and Mrs. Khodai in my preschool years to Ms. Kavitha, Mr. Barry and Mr. Urso in my high school years, for making me the student I am. Though I thank each and every one of my friends for their friendship and the happiness they brought into my life, I need especially to thank Mike Keller and Chiyanyidi Dennar because I would never have made it through undergrad without you. Among others, I would like to thank Bradley Brisson for inspiring me always to be a better person; a better friend. And finally, I'd like to thank Radhika Bhaskar because you bring out the best in me. Love you Boo. Always!! 


\section{Table of Contents}

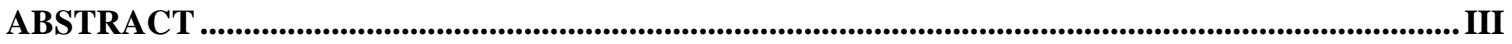

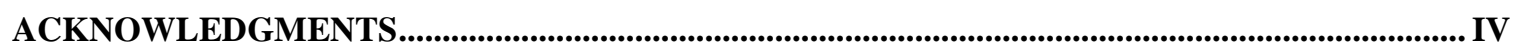

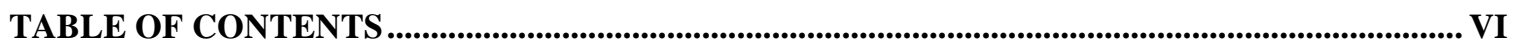

LIST OF FIGURES ...................................................................................................................................................... VIII

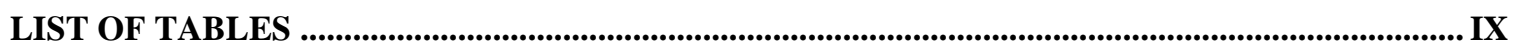

ABBREVIATIONS …........................................................................................................................................

CHAPTER 1: INTRODUCTION \& OBJECTIVES....................................................................................

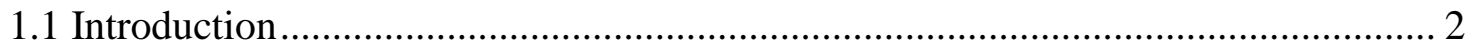

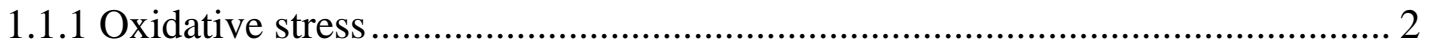

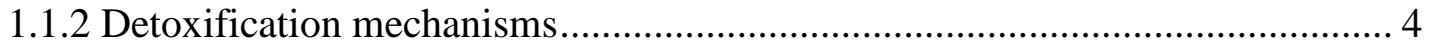

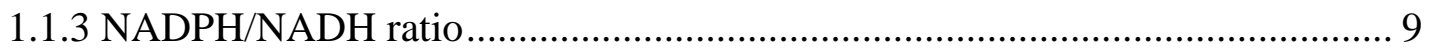

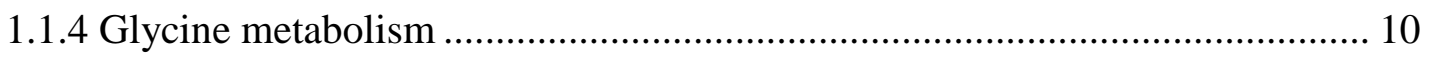

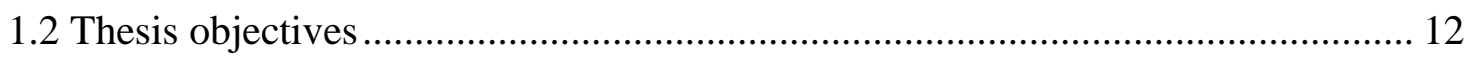

CHAPTER 2: THE ROLE OF FORMATE IN COMBATTING OXIDATIVE STRESS ....................13

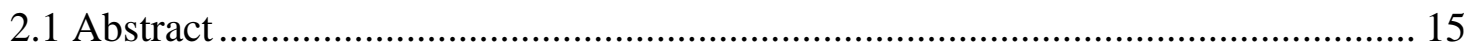

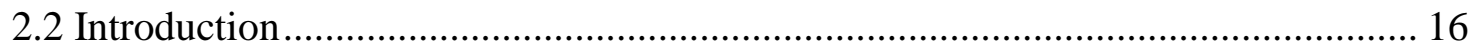

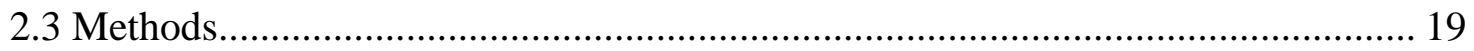


2.3.1 Growth of Pseudomonas fluorescens.......................................................... 19

2.3.2 Regulation and whole cell experiments .............................................. 20

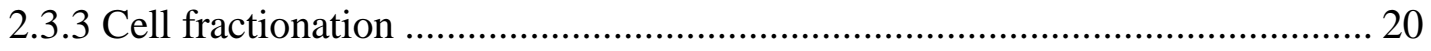

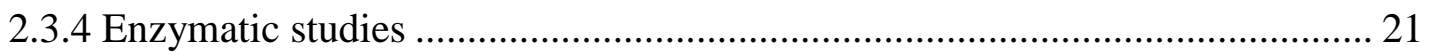

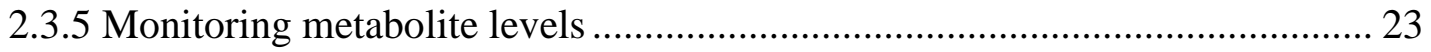

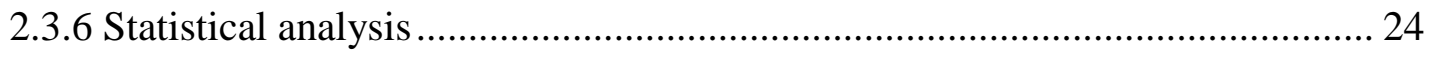

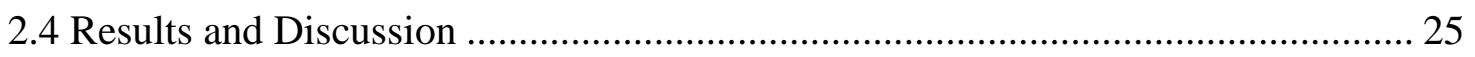

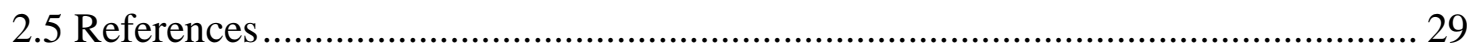

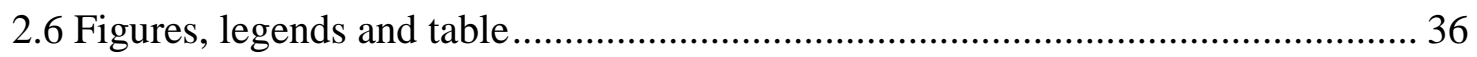

CHAPTER 3: CONCLUSION, FUTURE RESEARCH AND GENERAL BIBLIOGRAPHY ............41

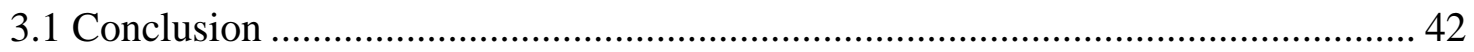

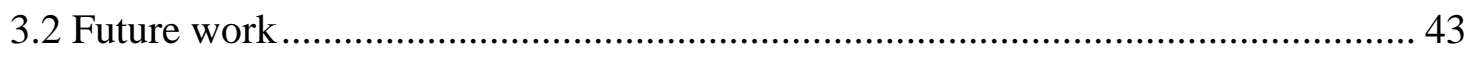

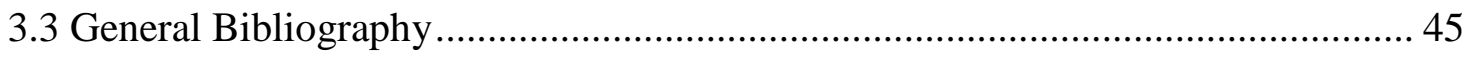

PUBLICATIONS AND COMMUNICATIONS ................................................................................................50 


\section{List of figures}

Figure 1.1: Tricarboxylic acid cycle and Electron Transport Chain.............................. 2

Figure 1.2: Free radical generation from oxygen................................................ 3

Figure 1.3: Detoxification of the superoxide anion by SOD. .................................. 5

Figure 1.4: Detoxification of superoxide anion using SOR ........................................ 5

Figure 1.5: Reduction of hydrogen peroxide via the two-step process.......................... 6

Figure 1.6: Detoxification of hydrogen peroxide via glutathione peroxidase .................. 7

Figure 1.7: Structures of vitamin E and Ascorbic acid. ............................................. 8

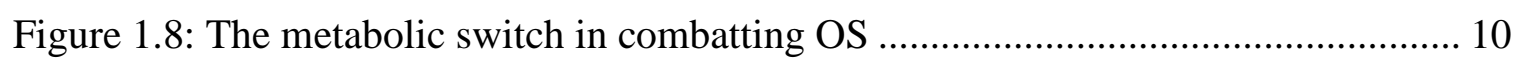

Figure 1.9: Glycine based metabolic shift to combat oxidative stress in Pseudomonas

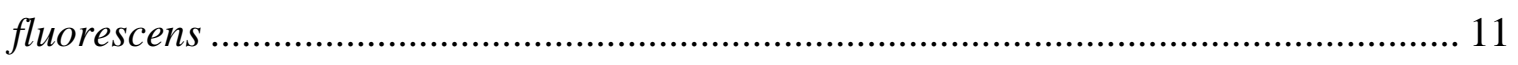

Figure 2.1: Formate production in P. fluorescens .....................................36

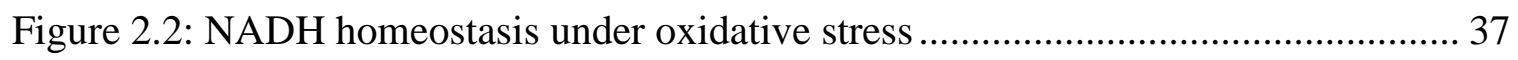

Figure 2.3: Formate-dependent succinate production............................................. 38

Figure 2.4: Schematic demonstrating the metabolic shift involving the role of formate in P. fluorescens in combatting oxidative stress................................. 39 


\section{List of tables}

Table 1. Monitoring the activity of the select enzymes using spectrophotometric assays 


\section{Abbreviations}

\begin{tabular}{|c|c|}
\hline$\alpha \mathrm{KG}$ & Alpha ketoglutarate \\
\hline $\mathrm{BN}$ & Blue Native \\
\hline CSB & Cell storage Buffer \\
\hline g & gram \\
\hline $\mathrm{GDH}$ & Glycine dehydrogenase \\
\hline GTA & Glycine Transaminase \\
\hline GSH & Glutathione \\
\hline $\operatorname{Hr}(\mathrm{s})$ & hour(s) \\
\hline ICL & Isocitrate lyase \\
\hline $\mathrm{INT}^{\mathrm{O}}$ & Iodonitro Tetrazolium salt (oxidized) \\
\hline $\mathrm{INT}^{\mathrm{R}}$ & Iodonitro Tetrazolium salt (reduced) \\
\hline $\mathrm{L}$ & Liter \\
\hline $\mathrm{mL}$ & milliliter \\
\hline $\min$ & minute \\
\hline $\mathrm{mM}$ & Millimolar \\
\hline NAD & Nicotinamide adenine dinucleotide (oxidized form) \\
\hline
\end{tabular}




$\begin{array}{ll}\text { NADH } & \text { Nicotinamide adenine dinucleotide (reduced form) } \\ \text { NADP } & \text { Nicotinamide adenine dinucleotide phosphate (oxidized form) } \\ \text { NADPH } & \text { Nicotinamide adenine dinucleotide phosphate (reduced form) } \\ \text { PAGE } & \text { Polyacrylamide Gel electrophoresis } \\ \text { PMS } & \text { Phenazine Methosulfate (oxidized) } \\ \text { PMS } & \text { Phenazine Methosulfate (reduced) } \\ \text { ROS } & \text { Reactive oxygen species } \\ \text { RNS } & \text { Reactive nitrogen species } \\ \text { Sec } & \text { Seconds } \\ \text { TCA } & \text { Tricarboxylic acid } \\ & \text { Volt }\end{array}$


CHAPTER 1: Introduction \& Objectives 


\subsection{Introduction}

\subsubsection{Oxidative stress}

Cellular metabolism underlies the creation of adenosine triphosphate (ATP), the universal metabolic currency of all organisms. Two major processes are utilized by cells to create ATP, substrate level phosphorylation and oxidative phosphorylation (Rodgers and Wilce, 2000). The latter utilizes oxygen to receive the electrons shunted through the tricarboxylic acid cycle as seen in figure 1.1.

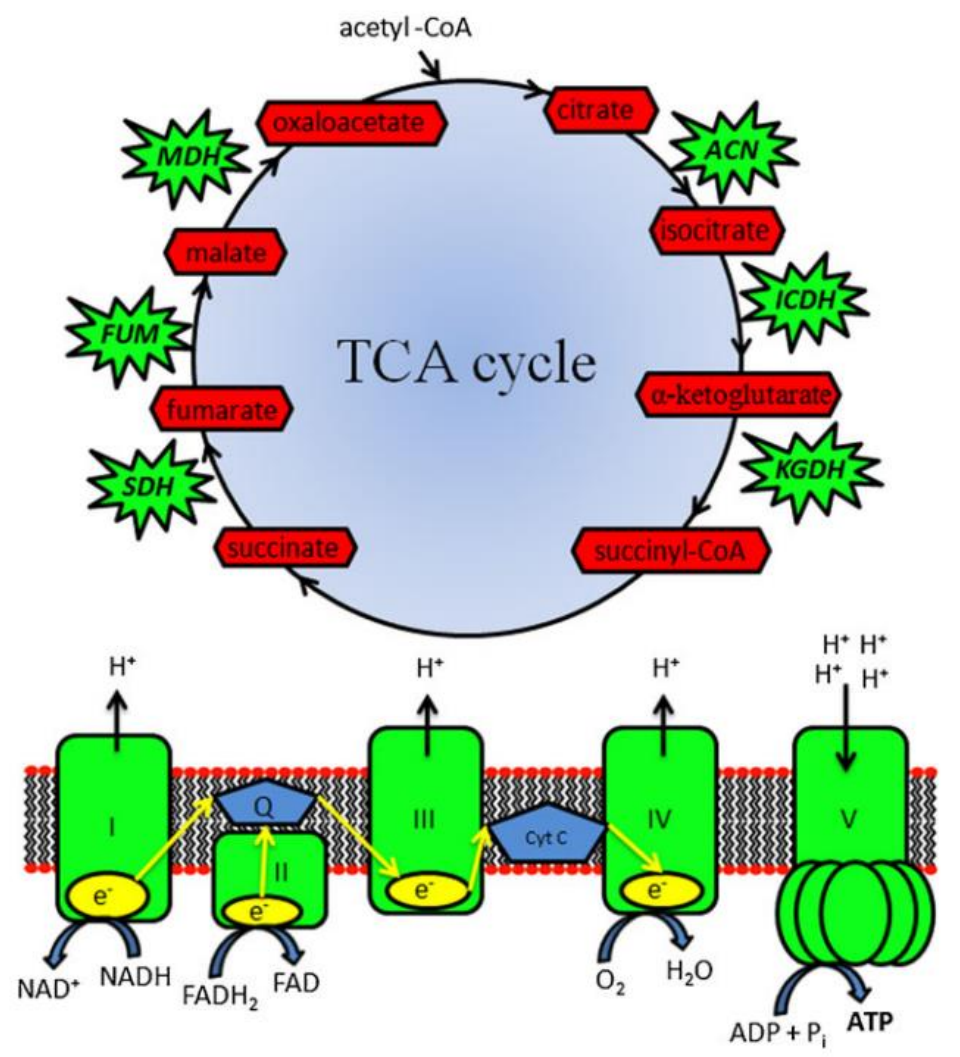

Figure 1.1: Tricarboxylic acid cycle and Electron Transport Chain 
The use of oxygen in this ETC primes the system for the creation of oxidative stress. It is estimated that $2-5 \%$ of all the $\mathrm{O}_{2}$ used in the ETC undergoes incomplete reduction by electron leakage which in turn results in higher levels of reactive oxygen species (Cadenas and Davies, 2000). The production of superoxide and hydrogen peroxide occurs in the cytoplasm upon the collision of oxygen with various redox enzymes with solvent exposed flavins (Imlay, 2009). Reactive oxygen species formation can cascade as exemplified in figure 1.2. These ROS may result in metabolic defects, damage to DNA and a variety of other biomolecules (Slauch, 2011).

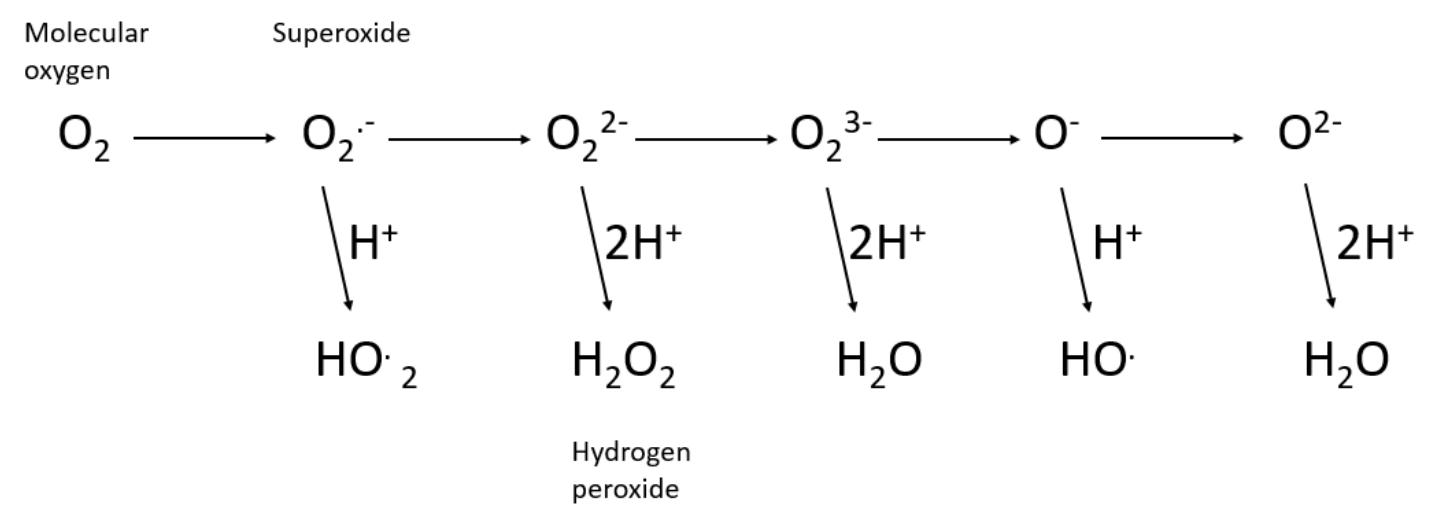

Figure 1.2: Free radical generation from oxygen.

ROS are important components of the antimicrobial defense mechanism incorporated by macrophages and neutrophils (Slauch, 2011). For instance NADPH-dependent phagocytic oxidases (Phox or NOX2) are assembled within the membrane and pump electrons into the compartment to form superoxide anions $\left(\mathrm{O}_{2}^{-}\right)$which then bombard the invading microbes (Slauch, 2011). As such, several microbes have devised extensive metabolic adaptation strategies to combat 
the oxidative stress. By definition oxidative stress simply refers to an imbalance in the prooxidant/antioxidant ratio in favor of the former which leads to possible damage (Sies, 1997). Understanding the mechanisms employed by microorganisms to combat this oxidative stress may in the long term provide cues for pharmacologic therapeutic intervention against them. The metabolically versatile Pseudomonas fluorescens is a model system for studying some of these adaptation strategies due to its flexible metabolic reconfiguration in the face of stress. It is a gramnegative rod shaped non-pathogenic bacterium that thrives primarily in the soil but on plants and in water surfaces as well (Paulsen et al., 2005) It has simple nutritional requirements and is able to readily grow in mineral media supplemented with a variety of carbon sources (O'sullivan and O’Gara, 1992, Auger et al., 2012).

\subsubsection{Detoxification mechanisms}

Due to the oxygen-rich atmosphere, microbes are posed with a constant threat of ROS and rely on a vast reserve of enzymes to eliminate the bulk of the stress. Two principal mechanisms govern the maintenance of redox homeostasis; one is predicated on controlling of the redox properties of metalloproteins (NADPH independent) while the other depends on the reduction of NADPH, the latter of which is discussed further in the next section (Mailloux et al., 2010).

The superoxide dismutase family of enzymes catalyse the metal-dependent dismutation of $\mathrm{O}_{2}{ }^{-}$to $\mathrm{H}_{2} \mathrm{O}_{2}$. Given that the spontaneous reduction of superoxide is unfavorable, the enzymes use two steps to drive the reaction. In the first, SOD accelerates the reduction of the radical anion by 
donation of a proton and in the energy generated is utilized to drive the second step with a net result of $\mathrm{O}_{2}$ and $\mathrm{H}_{2} \mathrm{O}_{2}$ as seen in figure 1.3 (Wang et al., 2006).

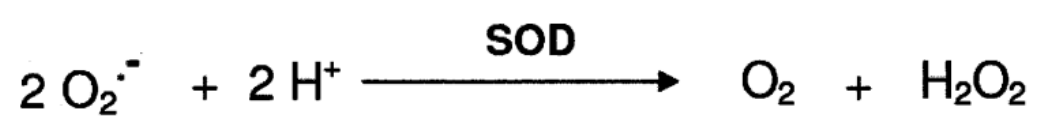

\section{Figure 1.3: Detoxification of the superoxide anion by SOD.}

Otherwise, some organisms such as Desulfovibrio baarsi, Acheoglobus fulgidus and Treponema pallidum utilize superoxide reductase (SOR), a small metalloprotein with an ironcontaining active site. They detoxify the superoxide anion into hydrogen peroxide as seen in figure 1.4 (Lombard et al., 2000; Niviere and Fontecave, 2004).

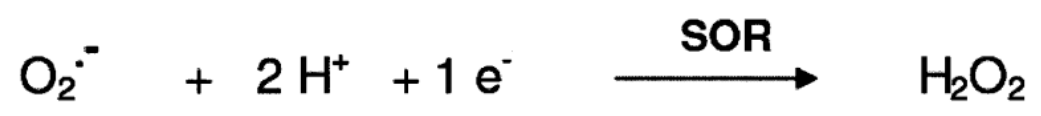

Figure 1.4: Detoxification of superoxide anion using SOR.

Albeit SOD and SOR assist organisms in converting superoxide anions into peroxide, further detoxification is required to quell the threat posed by $\mathrm{H}_{2} \mathrm{O}_{2}$.

Most commonly utilized with this aim are the catalase enzymes. The majority of catalases are formed of 4 subunits of 60-75 kDa (Kirkman and Gaetani, 2006). The dismutation of hydrogen 
peroxide is accomplished by utilizing the catalytic power of the iron-containing heme groups (figure 1.5) (Kirkman and Gaetani, 2006, Wang et al., 2006).

\section{$\mathrm{Enz}-\mathrm{Fe}(\mathrm{III})+\mathrm{H}_{2} \mathrm{O}_{2} \longrightarrow \mathrm{Enz}{ }^{\circ}-\mathrm{Fe}(\mathrm{IV})=\mathrm{O}+\mathrm{H}_{2} \mathrm{O}$ \\ $\mathrm{Enz}-\mathrm{Fe}(\mathrm{IV})=\mathrm{O}+\mathrm{H}_{2} \mathrm{O}_{2} \longrightarrow \mathrm{O}_{2}+\mathrm{Enz}-\mathrm{Fe}(\mathrm{III})+\mathrm{H}_{2} \mathrm{O}$}

\section{Figure 1.5: Reduction of hydrogen peroxide via the two-step process.}

In addition to catalases, thiol-dependent peroxidases also assist in the detoxification of peroxide. These contain small non-heme proteins which catalyse the single electron reduction of peroxides into their corresponding alcohols and depend on their reactive cysteine in the active site (Dubbs and Mongkolsuk, 2007; Poole, 2003). Glutathione peroxidases which are the best

characterized peroxidases, mediate the rapid reduction of hydrogen peroxide via the use of a covalently-incorporated selenium in the active site (figure 1.6) (Espinoza et al., 2010; Ursini et al., 1995). 


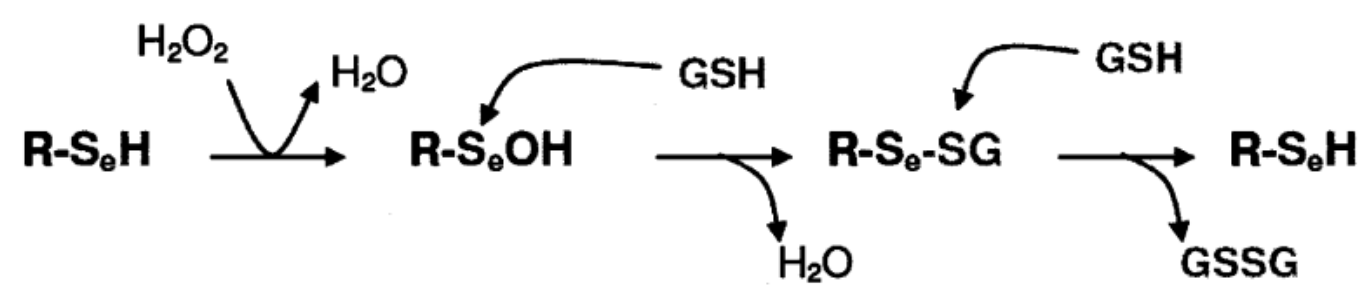

Figure 1.6: Detoxification of hydrogen peroxide via glutathione peroxidase.

In addition to the enzyme-based antioxidative defenses set up by numerous organisms, several incorporate a spectrum of low molecular weight molecules (called low molecular weight antioxidants (LMWA)) which they utilize to scavenge ROS (Grune et al., 2005).

One such moiety is vitamin C, also known as ascorbic acid (Figure 1.7), which is a watersoluble vitamin that reacts with free radicals leading to the generation of an unstable ascorbyl radical which can subsequently be recycled by $\mathrm{NAD}(\mathrm{P}) \mathrm{H}$ - or Glutatione (GSH)-mediated enzymatic activities (Grune et al., 2005; Shao et al., 2008).

Another important LMWA is vitamin E which is a lipid-soluble chain-breaking antioxidant which functions by dividing the compounds into tocopherols or tocotrienols (Figure 1.7). These are lipophilic antioxidants which interact with the polyunsaturated acyl groups of lipids, thereby stabilizing membranes. They scavenge ROS as well as the lipid soluble byproducts of OS (Grune et al., 2005). 
Ascorbic acid<smiles>O=C1O[C@H](CO)[C@H](O)C1O</smiles>

$\alpha$-Tocopherol

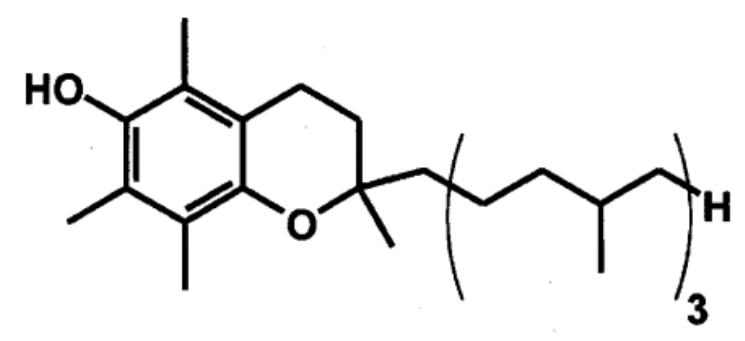

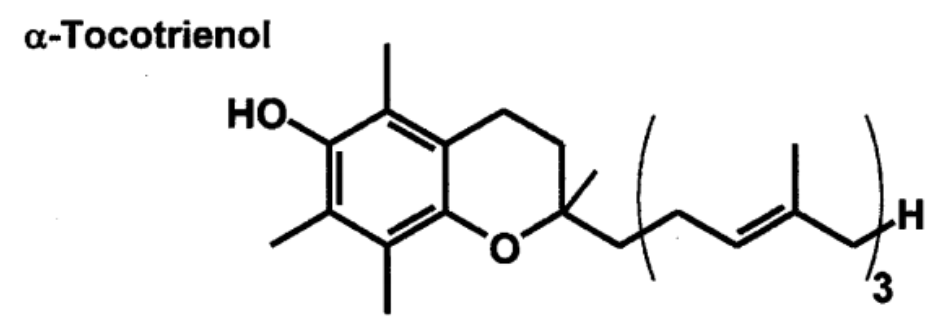

Figure 1.7: Structures of vitamin $E$ and Ascorbic acid.

Complex gene regulation controls these detoxification mechanisms and involves genes such as OxyR, AhpC, and SoxRS (D'Autreaux and Toledano, 2007; Dubbs and Mongkolsuk, 2007; Luschak, 2001). The aforementioned mechanisms of ROS detoxification work in tandem to enable cells to thrive even in toxic oxygenated environments. In recent times the role of metabolism and metabolic shifts in combatting oxidative stress has been greatly studied and elucidated (Mailloux et al., 2006; Ralser et al., 2009). By modulating the catabolic and anabolic pathways, organisms are able to produce key metabolites in the fight against ROS as well as limit the production of pro-oxidants by the TCA cycle. 


\subsubsection{NADPH/NADH ratio}

Several ROS-scavenging systems such as glutathione reductase (GR), as well as ascorbate require NADPH to reduce and regenerate their oxidized active sites whereas others such as catalase utilize NADPH in order to avoid the formation of intermediates which hinder the ability of the enzyme to function (Kirkman and Gaetani, 2006; Singh et al., 2007). Since NADPH is a key component of the anti-oxidative defense mechanisms of cells, NADPH-generating enzymes are highly active under oxidative stress. Some classical enzymes which have been extensively studied include glucose-6-phosphate dehydrogenase (G6PDGH), malic enzyme (ME), NADP-dependent isocitrate dehydrogenase (NADP-ICDH) and NADP glutamate dehydrogenase (NADP-GDH). These function to produce NADPH, thereby keeping the cytosolic compartments of the cell in a constantly reduced environment (Mailloux et al., 2010).

In combatting OS, P. fluorescens for instance will not only promote the production of NADPH but will concomitantly decrease the formation of nicotinamide adenine dinucleotide hydride (NADH) with the aim to limit ROS emission from the respiratory chain (Singh et al., 2008). Thus the oxidation of NADH via the complexes of the electron transport chain, I, III and IV which also result in intracellular generation of ROS are diminished (Singh et al., 2008). In summary the combat against OS involves a two pronged approach which ultimately results in the increased production of NADPH and the reduction in the production of NADH (Figure 1.8). For Pseudomonas fluorescens cultures grown in citrate media with glycine, this ratio is modulated via 
a plethora of metabolic changes. The role of ketoacids in this is only recently begun to be unravelled (Lemire et al., 2010).

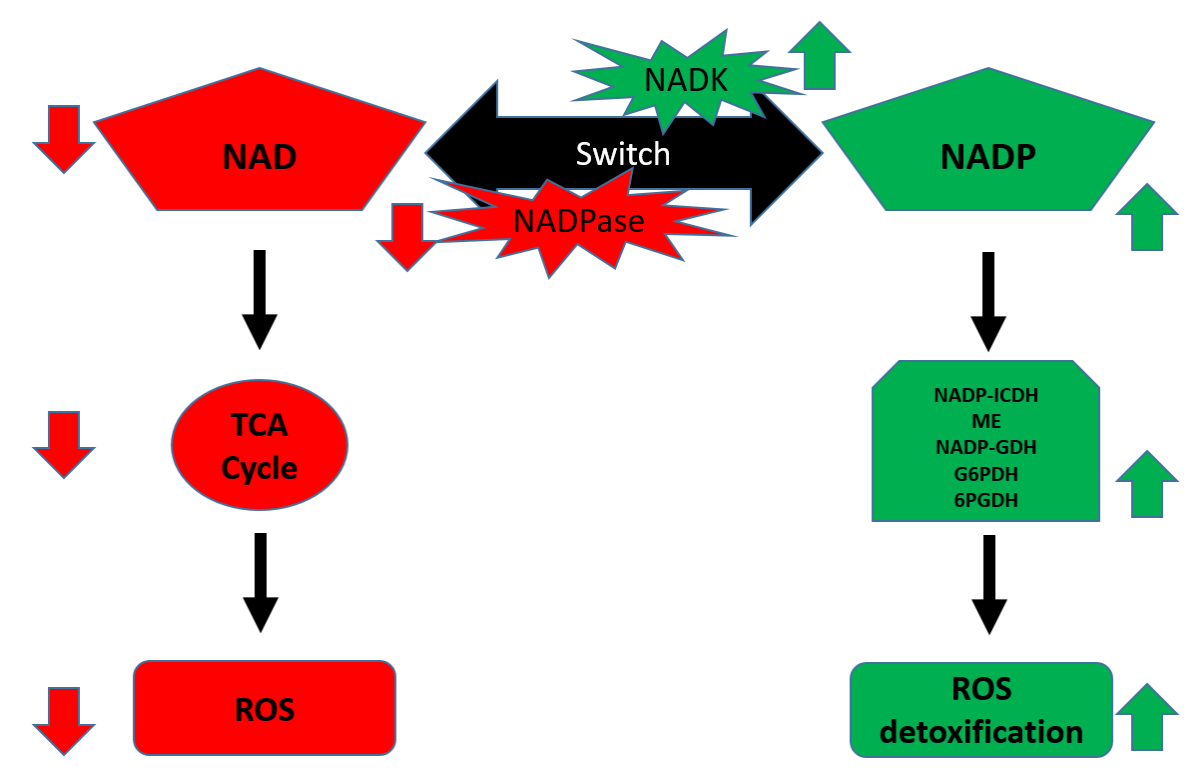

Figure 1.8: The metabolic switch in combatting OS (modified from Mailloux et al., 2010).

\subsubsection{Glycine metabolism}

Ketoacids react with ROS and concomitantly form their corresponding carboxylic acid as well as $\mathrm{CO}_{2}$. Pyruvate for example forms acetate by non-enzymatic decarboxylation when neutralizing $\mathrm{H}_{2} \mathrm{O}_{2}$. Similarly $\alpha \mathrm{KG}$ detoxifies $\mathrm{ROS}$ and produces succinate in the process (Bignucolo et al., 2013). The production of succinate has the added benefit of fulfilling its role of ketoacids as a potent antioxidant tool (Kohen and Nyska, 2002). 
When Pseudomonas fluorescens is grown in citrate media exposed to oxidative stress, it shifts their metabolism to produce three key metabolites, ATP, NADPH and glyoxylate to neutralize this threat (Alhasawi et al., 2015). Three key enzymes related to the formation of glyoxylate, Glycine dehydrogenase (GDH), Glycine transaminase (GTA) and Isocitrate lyase (ICL) were found to be upregulated in the oxidatively stressed cells. The production of this ketoacid was discovered to have multiple fates. First was the non-enzymatic decarboxylation into formate and the second was the formation of oxalyl-CoA which is hypothesized to contribute to the formation of ATP. A summary of this is presented in figure 1.9.

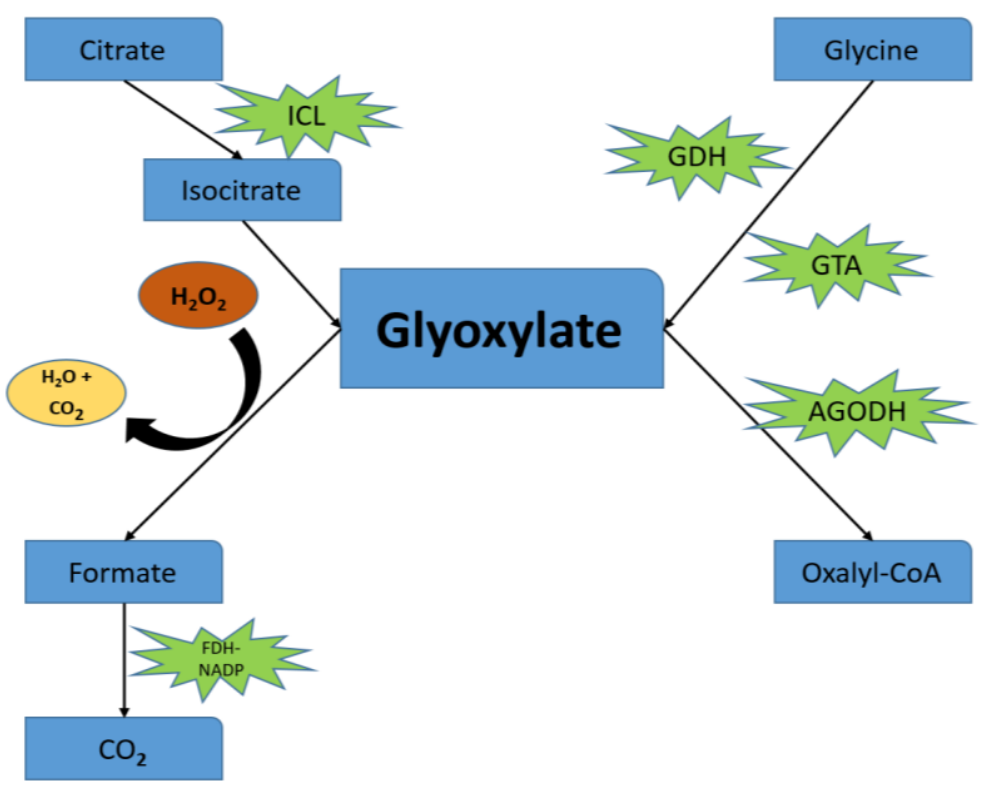

Figure 1.9: Glycine based metabolic shift to combat oxidative stress in Pseudomonas fluorescens (Modified from Alhasawi et al., 2015). 
The role of the formate generated as consequence of the interaction of glyoxylate with ROS is thought to contribute to NADPH homeostasis. The current study aims at deciphering the contribution of formate in anti-oxidative defense.

\subsection{Thesis objectives}

The primary objective of this research work is to delineate the role formate plays in Pseudomonas fluorescens in combatting oxidative stress. The fate of formate as well as its role in neutralizing oxidative stress can be gauged via a functional proteomic and metabolomics approach using techniques such as blue native polyacrylamide gel electrophoresis (BNPAGE), and high performance electrophoresis (HPLC). The metabolic versatility of $P$. fluorescens makes it an ideal system to evaluate mechanisms involved in fending oxidative stress. In addition to the analysis of antioxidant defense systems, understanding the enzymes mediating the catabolism of various nutritional sources and the metabolites utilized to scavenge ROS will help devise strategies to quell microbes that are resistant to antibiotics possibly by targeting the formate-producing enzymes. 
CHAPTER 2: The role of formate in combatting oxidative stress 
The role of formate in combatting oxidative stress.

Sean. C. Thomas, Azhar. Alhasawi, Christopher. Auger, Abdelwahab. Omri \& Vasu. D.

\author{
Appanna
}

Faculty of Science, Engineering and Architecture.

Laurentian University,

Sudbury, Ontario, P3E 2C6.

Canada

Published in Antonie van Leeuwenhoek, Journal of Microbiology; November 2015, DOI : $10.1007 / s 10482-015-629-6$

Copyright (C) Springer International Publishing Switzerland 2015 


\subsection{Abstract}

The interaction of keto-acids with reactive oxygen species (ROS) is known to produce the corresponding carboxylic acid with the concomitant formation of $\mathrm{CO}_{2}$. Formate is liberated when the keto-acid glyoxylate neutralizes ROS. Here we report on how formate is involved in combating oxidative stress in the nutritionally-versatile Pseudomonas fluorescens. When the microbe was subjected to hydrogen peroxide $\left(\mathrm{H}_{2} \mathrm{O}_{2}\right)$, the levels of formate were 8 and 2 -fold higher in the spent fluid and the soluble cell-free extracts obtained in the stressed cultures compared to the controls respectively. Formate was subsequently utilized as a reducing force to generate NADPH and succinate. The former is mediated by formate dehydrogenase (FDH-NADP), whose activity was enhanced in the stressed cells. Fumarate reductase (FRD) that catalyzes the conversion of fumarate into succinate was also markedly increased in the stressed cells. These enzymes were modulated by $\mathrm{H}_{2} \mathrm{O}_{2}$. While the stressed whole cells produced copious amounts of formate in the presence of glycine, the cell-free extracts synthesized ATP and succinate from formate. Although the exact role of formate in anti-oxidative defense has to await further investigation, the data in this report suggest that this carboxylic acid may be a potent reductive force against oxidative stress.

Keywords: Formate metabolism, Pseudomonas fluorescens, ketoacids, glyoxylate, Formate dehydrogenase, Fumarate reductase- formate dependent, Isocitrate lyase. 


\subsection{Introduction}

As oxidative stress is part of aerobic life, most organisms have evolved intricate mechanisms to circumvent this challenge. These strategies include the utilization of enzymes such as catalase, superoxide dismutase (SOD) and glutathione peroxidase which aid in the lowering of oxidative tension during aerobic respiration (Brioukhanov, Netrusov \& Eggen, 2006). Recently the significance of ketoacids in combatting reactive oxygen species (ROS) has emerged. The moieties like alpha ketoglutarate $(\alpha \mathrm{KG})$, oxaloacetate (OAA), pyruvate and glyoxylate scavenge ROS with the concomitant formation of their respective carboxylic acid (Alhasawi et al., 2015a; Lemire et al., 2011; Mailloux, Puiseux-Dao \& Appanna, 2008; Singh et al., 2008; Li et al, 2010; Thomas et al., 2015). When glyoxylate is utilized as an ROS scavenger, formate is one of the critical byproducts formed (Alhasawi et al., 2015b; Yokota, Kawabata \& Kitaoka, 1983; Yokota, Komura \& Kitaoka, 1985). In numerous bacteria, plants and animals formate is an important metabolite involved in energy metabolism (Hourton-Cabassa et al., 1998; Leonharsberger, Korsa \& Bock, 2002). Its favourable redox potential enables this monocarboxylic acid to be oxidized not only through the aerobic respiratory pathways but to serve as an electron donor for the reduction of key

metabolites such as fumarate, nitrate and nitrite (Bagramyan, Galstyan \& Trchounian, 2000; Jormakka et al., 2002; Shinagawa et al., 2008; Su \& Puls, 2004)

Formate may undergo different fates in these bacteria depending on the physiological conditions (Leonhartsburger et al., 2002). It may be secreted, oxidised aerobically, used as a reductant or converted into $\mathrm{CO}_{2}$ and $\mathrm{H}_{2}$ via the enzyme formate hydrogen lyase (Bagramyan \& 
Trchounian, 2003; Yoshida et al., 2005). A key enzyme in the metabolism of formate is formate dehydrogenase $(\mathrm{FDH})$. In some bacteria this enzyme predominantly utilizes nitrate as an electron acceptor (Uchimura et al., 2002). FDH plays a pivotal role in respiration as well as in the maintenance of a reducing environment (Jormakka, Byrne \& Iwata, 2002). These enzymes have been reported with differing cofactor requirements, electron acceptors, substrates and cellular locations (Hourton Cabassa et al., 1998). The FDHs NAD-dependent which have been extensively studied in both bacteria, yeast and plants, have been widely utilized in industry for NADH regeneration (Alekseeva, Savin \& Tishkov, 2011; Hoelsch et al., 2013; Suzuki et al., 1998).The occurrence of FDH NADP-dependent has also been reported (Yamamoto et al., 1983; GulKaraguler et al., 2001). FDH synthesis has been shown to increase strongly under conditions of stress including abrupt changes in temperature, irradiation with UV light, hypoxia and chemical agents and may contribute in maintaining NADPH homeostasis (Abdreadeku et al., 2009; Andreadeli et al., 2009; Hoelsch et al., 2013; Hourtan Cabassa et al., 1998).

The role of this monocarboxylic acid in providing the reducing power to the pivotal ribonucleotide reductase has been shown (Stubbe et al., 2003). This enzyme participates in the synthesis of deoxyribonucleotides with the concomitant formation of $\mathrm{CO}_{2}$. Deoxyribonucleotides are critical in the cellular replication and their formation usually necessitates the utilization of NADPH. As part of our study to unravel the significance of metabolic pathways in anti-oxidative defense, we have evaluated the role of formate in the adaptation of the nutritionally-versatile microbe Pseudomonas fluorescens to oxidative stress. Here we report that the presence of the 
enhanced level of this mono- carbon carboxylic acid is an important source of reducing power in the $\mathrm{H}_{2} \mathrm{O}_{2}$-challenged cells. It participates in the synthesis of NADPH and contributes to the reduction of fumarate to succinate, biological reactions that ensure the survival of the microbe in an oxidative milieu. The importance of formate as a substitute for NADH in environments where the tricarboxylic acid (TCA) cycle and oxidative phosphorylation (OP) are ineffective is also discussed. 


\subsection{Methods}

\subsubsection{Growth of Pseudomonas fluorescens}

Pseudomonas fluorescens from American type culture collection (ATCC13525) was grown in defined citrate/glycine media (control), consisting of $\mathrm{Na}_{2} \mathrm{HPO}_{4}(6 \mathrm{~g}), \mathrm{KH}_{2} \mathrm{PO}_{4}(3 \mathrm{~g}), 15$ $\mathrm{mM}$ glycine $(1.2 \mathrm{~g}), \mathrm{MgSO}_{4} .7 \mathrm{H}_{2} \mathrm{O}(0.2 \mathrm{~g})$, and $19 \mathrm{mM}$ citrate $(4 \mathrm{~g})$ with a $\mathrm{pH}$ of 6.8 . Additionally, trace elements were added as described in (Mailloux et al., 2008). Media were dispensed into 200 $\mathrm{mL}$ aliquots in two $500 \mathrm{~mL}$ Erlenmeyer flasks (control and stress conditions) and autoclaved for 20 minutes at $121{ }^{\circ} \mathrm{C}$ prior to the inoculation with $1 \mathrm{ml}$ of bacteria grown to stationary phase in a control medium (same conditions as control culture from the experiment). Oxidative stress in the stressed culture was introduced by the addition of final concentration of $500 \mu \mathrm{M} \mathrm{H}_{2} \mathrm{O}_{2}$, an amount known to elicit maximal antioxidative response (Alhasawi et al., 2015a,b). All cultures were aerated in a gyratory water bath shaker, model 76 (New Brunswick Scientific) at $26^{\circ} \mathrm{C}$ at $140 \mathrm{rpm}$. The cells and spent fluid were isolated at the stationary phase of growth for metabolomic and enzymatic analyses ( $28 \mathrm{~h}$ for control and $50 \mathrm{~h}$ growth for the $\mathrm{H}_{2} \mathrm{O}_{2}$ stressed cultures). Following the harvesting of cells at various growth intervals, the bacterial pellets were treated with $0.5 \mathrm{~N} \mathrm{NaOH}$ and cell growth was monitored by measuring the solubilized protein using the Bradford assay (Bradford 1976). 


\subsubsection{Regulation and whole cell experiments}

In the regulation experiments, to assess the adaptive and reversible nature of the shifts in metabolism, cells were harvested at stationary phase of growth. Control cells (10 mg protein equivalent) were incubated for 8 hours in $50 \mathrm{~mL}$ media containing $500 \mu \mathrm{M} \mathrm{H}_{2} \mathrm{O}_{2}$ whereas the $\mathrm{H}_{2} \mathrm{O}_{2-}$ stressed cells were incubated for 8 hours in $50 \mathrm{~mL}$ control media as described in (Alhasawi et al., 2014). The cell-free extracts and the spent fluid were subsequently analyzed for metabolites and enzymatic activities.

To evaluate the source of formate production, whole cells ( $10 \mathrm{mg}$ protein equivalent) from the control and stress cultures were incubated for 8 hours in separate media $(50 \mathrm{~mL})$ containing the same growth nutrients as the control culture but with only citrate or glycine in the presence and in the absence of $\mathrm{H}_{2} \mathrm{O}_{2}$. To monitor the rate of formate utilization, $10 \mathrm{mg}$ protein equivalent of control and stressed whole cells were incubated in reaction mixture containing $5 \mathrm{mM}$ formate and the consumption of the monocarboxylic acid was recorded by HPLC after 8 hours.

\subsubsection{Cell fractionation}

Following the isolation of the bacteria at $4{ }^{\circ} \mathrm{C}$ for 10 minutes at $10,000 \mathrm{~g}$ with the aid of a Sorvall Legend RT Centrifuge, cells were washed with $0.85 \% \mathrm{NaCl}$ and respun before being resuspended in $500 \mu \mathrm{L}$ cell storage buffer (CSB) consisting of $50 \mathrm{mM}$ Tris- $\mathrm{HCl}, 5 \mathrm{mM} \mathrm{MgCl} 2$ and $1 \mathrm{mM}$ fluoride (PMSF). Sonication was utilized to lyse the cells (unbroken cells were removed by centrifugation at $10,000 \mathrm{~g}$ ). These were centrifuged at $180,000 \mathrm{~g}$ for $3 \mathrm{~h}$ at $4{ }^{\circ} \mathrm{C}$ yielding a soluble 
cell-free (CFE) and a membrane fraction. The membrane fraction was suspended in $500 \mu \mathrm{L}$ of CSB. The Bradford assay was utilized to determine protein content with serum bovine albumin as the standard. Equal protein concentrations were utilized in all experiments.

\subsubsection{Enzymatic studies}

BN-PAGE was executed as per the protocol described in, Auger et al. (2015); Mailloux et al. (2008) and Schagger and von Jagow (1991). For these assays, a 4-16\% gradient gel was prepared and the protein $(4 \mu \mathrm{g} / \mu \mathrm{L})$ was prepared in blue native buffer $(400 \mathrm{mM} 6$-amino hexanoic acid, $50 \mathrm{mM}$ Bis-Tris [pH 7.0]). To solubilize membrane bound proteins in order to ensure optimal protein separation, a final concentration of $1 \%$ dodecyl- $\beta$-maltoside was added to the membrane fractions. Protein samples were loaded into each well of the native gel $(10-60 \mu \mathrm{g})$ and electrophoresed at $4{ }^{\circ} \mathrm{C}$ under native conditions at $80 \mathrm{~V}$ and $15 \mathrm{~mA}$ for proper stacking followed by $150 \mathrm{~V}$ and $25 \mathrm{~mA}$ in the resolving gel for the migration of the protein until it travelled half-way through the gel. At the halfway point, blue cathode buffer (50 mM Tricine, $15 \mathrm{mM}$ Bis-Tris, $0.02 \%$ w/v Coomassie G-250, $\mathrm{pH} 7$ at $4{ }^{\circ} \mathrm{C}$ ) was changed to a colorless cathode buffer (50 mM Tricine, $15 \mathrm{mM}$ Bis-Tris, $\mathrm{pH} 7$ at $4{ }^{\circ} \mathrm{C}$ ) to provide improved detection of the protein bands and thence electrophoresis was performed at $300 \mathrm{~V}$ and $25 \mathrm{~mA}$. For 15 minutes following the electrophoresis, the gel was incubated in reaction buffer ( $25 \mathrm{mM}$ Tris- $\mathrm{HCl}, 5 \mathrm{mM} \mathrm{MgCl} 2[\mathrm{pH} 7.4])$, after which, the in-gel activity assay was performed by using a reaction mixture containing equilibrium buffer, $5 \mathrm{mM}$ substrate, $0.5 \mathrm{mM}$ cofactors, $0.2 \mathrm{mg} / \mathrm{mL}$ phenazine methosulfate (PMS) or 
dichloroindophenol (DCIP), and $0.5 \mu \mathrm{g} / \mathrm{mL}$ iodonitrotetrazolium (INT) in a total volume of $3 \mathrm{~mL}$. For FDH-NADP, this consisted of $5 \mathrm{mM}$ formate and $0.5 \mathrm{mM}$ NADP whereas the FDH-NAD utilized $0.5 \mathrm{mM}$ NAD instead. To confirm the presence of these enzymes the activity bands were cut and incubated in $1 \mathrm{~mL}$ reaction mixtures containing the corresponding substrates bicarbonate and NADPH and NADH respectively while monitoring the formation of formate via HPLCs. Fumarate reductase was detected using $5 \mathrm{mM}$ fumarate and $0.5 \mathrm{mM}$ formate. Confirmation was obtained by incubating the excised bands in a mixture containing fumarate $(5 \mathrm{mM})$ and formate $(0.5 \mathrm{mM})$ and monitoring for succinate production. Isocitrate lyase, Complex I and NADH were monitored as described in (Auger et al., 2015). Destaining solution (40\% methanol and 10\% glacial acetic acid) was used to stop the reactions where appropriate. Coomassie staining was used to ensure equal protein loading. The specificity in detections was further confirmed by performing in-gel reactions in the absence of a substrate or by the addition of the inhibitor sodium azide $(5 \mathrm{mM})$. Densitometry was performed using imageJ for windows.

Spectrophotometric data for NAD-dependent isocitrate dehydrogenase (ICDH-NAD) was obtained by incubating $1 \mathrm{mg}$ (protein equivalent) of membrane fraction from control and $\mathrm{H}_{2} \mathrm{O}_{2-}$ treated cells with $2 \mathrm{mM}$ isocitrate and $0.5 \mathrm{mM}$ NAD for $1 \mathrm{~min}$. For NADP-dependent ICDH, NADP was used instead of NAD. To monitor malate dehydrogenase (MDH), malate and NAD were utilized. A similar reaction was used for malic enzyme (ME) except NAD was replaced with NADP. NADH and NADPH production were monitored at $340 \mathrm{~nm}$ over the course of a minute. Negative controls were performed without the substrates or cofactors. 


\subsubsection{Monitoring metabolite levels}

To evaluate the influence of $\mathrm{H}_{2} \mathrm{O}_{2}$ stress on metabolic networks, select metabolites (formate, succinate and ATP) were analysed by High Performance Liquid Chromatography (HPLC) (Alhasawi et al., 2015b). Briefly, following the harvesting of the cells at various timed intervals, the spent fluid and the soluble cellular fractions (CFE) were analyzed. An Alliance HPLC with C18 reverse-phase column (Synergi Hydro-RP; $4 \mu \mathrm{m} ; 250 \times 4.6 \mathrm{~mm}$, Phenomenex) and Waters dual absorbance detector were utilized. Mobile phase containing $20 \mathrm{mM} \mathrm{KH}_{2} \mathrm{PO}_{4}(\mathrm{pH}$ 2.9) was used at a flow-rate of $0.2 \mathrm{~mL} / \mathrm{min}$ at ambient temperature to separate the substrates and products, which were measured at $210 \mathrm{~nm}$ and $280 \mathrm{~nm}$ respectively. Peaks were quantified using the Empower software (Waters Corporation and metabolites were identified by spiking biological samples using known standards). HPLC analyses were performed immediately after the reactions in order to minimize substrate and product degradation. Activity bands were excised from the gel and placed in $1 \mathrm{~mL}$ reaction mixture containing $2 \mathrm{mM}$ substrates for $30 \mathrm{~min}$ of incubation. To monitor FDH-NAD, the excised bands were incubated in reaction mixture containing bicarbonate and NADH whereas to monitor FDH-NADP, the excised bands were incubated in reaction mixture containing bicarbonate and NADPH and in both cases, formate formation was monitored. For fumarate reductase, the reaction mixture comprised fumarate and formate while monitoring for succinate production. The sample $(100 \mu \mathrm{L})$ was collected and diluted with $900 \mu \mathrm{L}$ milli-Q water for HPLC analysis. 


\subsubsection{Statistical analysis}

Data were expressed as means \pm standard deviations. Percent change was calculated where appropriate in order to account for individual variation and to provide a better measure of the change in activity. The quantitative data were checked for significance using the student $t$-test ( $p$ $\leq 0.05$ ). All experiments were performed in at least biological duplicates and repeated thrice each. 


\subsection{Results and Discussion}

When subjected to $500 \mu \mathrm{M} \mathrm{H}_{2} \mathrm{O}_{2}$, Pseudomonas fluorescens produced more formate in the growth media compared to the control cells at stationary phase (Figure 1A). This monocarboxylic acid is known to be a product of the detoxification of ROS by glyoxylate (Alhasawi et al., 2015b). Indeed, formate levels within the soluble cell free extract were also found to be significantly higher in the stressed cells compared to the control cells (Figure 1B). Additionally, when whole cells were incubated with either glycine or citrate for 8 hours, a sharp increase in formate levels was observed compared to the controls (Figure 1C). The activity of isocitrate lyase, an enzyme known to produce glyoxylate was also found to be elevated in the stressed cultures (Figure 1D) (Hamel et al., 2004). As formate was an important product in the cells challenged by $\mathrm{H}_{2} \mathrm{O}_{2}$, it was important to evaluate how this metabolite was utilized. The stressed whole cells incubated in reaction mixture containing formate consumed this carboxylic acid at a faster rate compared to the control whole cells (data not shown).

As formate was a key metabolite in the stressed cells, it was important to evaluate how this moiety was contributing to the anti-oxidative defense strategy of the microbe. There was a marked increase in the activity of FDH-NADP in the stressed cells (Figure 2A). In an effort to ascertain if this enzyme was being expressed as a consequence of oxidative stress, control cells were exposed to $\mathrm{H}_{2} \mathrm{O}_{2}$ medium while $\mathrm{H}_{2} \mathrm{O}_{2}$ challenged cells were incubated in a control medium. A marked reduction of FDH-NADP activity band was observed in the latter while in the former situation the activity band corresponding to the dehydrogenase was enhanced (Figure 2B). FDH-NADP was 
readily inhibited by sodium azide (Figure 2C). This enzyme may help contribute to the NADPH budget which is critical in combatting oxidative stress, as both malic enzyme and ICDH-NADP that are known to synthesize this reducing agent were also increased (Table 1) (Beriault et al., 2005; Beriault et al., 2007; Ying, 2008). The stressed cells were also characterized by an increase in FDH-NAD (Figure 2D) which was confirmed by excision of the activity band and incubation in reaction mixture containing NADH and bicarbonate to monitor formate production (Figure 2E). Furthermore this trend was reversed in the regulation experiment as observed (Figure 2F). However, the presence of $\mathrm{H}_{2} \mathrm{O}_{2}$ resulted in the diminution of the activities of TCA cycle enzymes like ICDH-NAD and MDH (Table 1). Also, Complex I was marked diminished in the stressed cultures (Figure $2 \mathrm{G}$ ) while the activity band indicative of NADH oxidase was barely evident in the control cells (Figure 2H).

Fumarate reductase (FRD) mediates the conversion of fumarate into succinate with concomitant oxidation of NADH (Appanna et al., 2014). Although this enzyme was present, it readily utilized formate as the reducing cofactor (Figure 3A). Formate is known to provide electrons with the liberation of $\mathrm{CO}_{2}$ (Zaunmuller et al., 2006). There was a drastic increase in formate dependent FRD in the stressed cells compared to the control cells where the activity band was only slightly visible (Figure 3A). Regulation experiments confirmed the reversible nature of this enzyme (Figure 3B). Furthermore, the formate dependent FRD was distinguished from the NAD-dependent FRD which also showed a marked increase in stress cells (Figure 3C). Incubation of the excised activity band of formate dependent FRD in fumarate and formate yielded succinate 
(Figure 3D). The membrane fraction from the stressed cells incubated in reaction mixture containing fumarate, formate and ADP for 30 minutes generated more ATP and succinate compared to the control cells (Figure 3E).

The data in this article point to the ability of formate to act as an important reducing factor in Pseudomonas fluorescens exposed to oxidative stress. This carboxylic acid that is referred to as reduced carbon dioxide is known to provide the reducing fuel in a variety of biochemical reactions in lieu of NADH and NADPH. Reduction of ribonucleotide, nitrite and cytochrome C has been shown to be mediated by formate (Stubbe et al., 2003). In this study, formate contributes to the anti-oxidative defense strategy by supplying NADPH. Although a variety of mechanisms are deployed by microorganisms including the synthesis of exopolysaccharides (Appanna \& Preston, 1987) to quell oxidative tension, there is a dearth of information on such a role for this carboxylic acid. This metabolite aided by the enzymes ME and ICDH-NADP, may allow P. fluorescens to battle the oxidative challenge posed by $\mathrm{H}_{2} \mathrm{O}_{2}$. Indeed, various organisms are shown to evoke intricate NADPH-generating pathways to modulate their NADPH budget to combat oxidative stress (Alhasawi et al., 2014; Chenier et al., 2008; Drummond et al., 2011; Spanier et al., 2009). The ability of formate to reduce fumarate to succinate with the aid of FRD may prove an added benefit to this microbe as the production of NADH is markedly diminished under oxidative tension (Mailloux et al., 2010). The TCA cycle, a key generator of the catabolic reducing agent, is severely impeded (Mailloux et al., 2007). Additionally, oxidative phosphorylation is downregulated as revealed by the diminished activity of Complex I, a situation that may impede the generation of 
NAD. To rectify such an occurrence, the microbe invokes the participation of NADH oxidase, an enzyme whose activity is known to be increased during environmental stress (Chenier et al., 2008). Although FDH-NAD may help alleviate the diminished NADH production in the $\mathrm{H}_{2} \mathrm{O}_{2}$ medium, the utilization of formate in $\mathrm{NADH}$-requiring processes like in the reduction of fumarate to succinate will be an added benefit during oxidative stress. Hence, reactions necessitating NADH may switch to formate as a reducing factor. The enhanced synthesis of glyoxylate fueled by the increased activity of ICL may argue for such a possibility. It is quite likely that Pseudomonas fluorescens may have adopted this strategy. Formate, a by-product of the detoxification of ROS by glyoxylate, may have aptly been utilized by this microbe as a potent reductive power.

Although further molecular studies are required to confirm the significance of formate in anti-oxidative defense, the findings in this study argue for the possibility that Pseudomonas fluorescens may invoke the participation of this carboxylic acid in fending the challenge posed by $\mathrm{H}_{2} \mathrm{O}_{2}$. Formate does not only help generate NADPH but also contributes to synthesize key metabolites like succinate that ensures the survival of the microbe. Hence, metabolic reconfiguration appears to be essential to the adaptation of any organism to changing environmental conditions and in this instance, an apparent by-product is recuperated to contribute to the anti-oxidative defense effort (Figure 4). 


\subsection{References}

Alekseeva AA, Savin SS, Tishkov VI (2011) NAD-dependent Formate dehydrogenase from plants. Acta Nat 3(4): 38-54

Alhasawi A, Auger C, Appanna VP, Chahma MH, Appanna VD (2014) Zinc toxicity and ATP production in Pseudomonas fluorescens. J Appl Microbiol 117:65-73

Alhasawi A, Leblanc M, Appanna ND, Auger C, Appanna VD (2015a) Aspartate metabolism and pyruvate homeostasis triggered by oxidative stress in Pseudomonas fluorescens: a functional metabolomics study. Metabolomics 11(6): 1792-1801

Alhasawi A, Castonguay Z, Appanna ND, Auger C, Appanna VD (2015b) Glycine metabolism and anti-oxidative defense mechanisms in Pseudomonas fluorescens. Microbiol Res 171:26-31

Andreadeli A, Felmatakis E, Axarli I, Dimou M, Udvardi MK, Katinakis P, Labrou NE (2009) Cloning and characterization of Lotus japonicus formate dehydrogenase: a possible correlation with hypoxia. Biochim Biophys Acta 1794:976-984

Appanna VD, Preston CM (1987) Manganese elicits the synthesis of a novel exopolysaccharide in an arctic Rhizobium. FEBS Lett 215(1):79-82

Appanna VP, Auger C, Thomas SC, Omri A (2014) Fumarate metabolism and ATP production in Pseudomonas fluorescens exposed to nitrosative stress. A van Leeuw J Microb 106(3):431-438

Auger C, Appanna ND, Alhasawi A, Appanna VD (2015) Deciphering metabolic 
networks by blue native polyacrylamide gel electrophoresis: A functional proteomic exploration. EuPa Open Proteom 7: 64-72

Bagramyan K, Galstyan A, Trchounian A, (2000) Redox potential is a determinant in the Escherichia coli anaerobic fermentative growth and survival effects of impermeable oxidant. Bioelectrochemistry 51(2): 151-156

Bagramyan K, Trchounian A (2003) Structural and functional features of formate hydrogen lyase, an enzyme of mixed-acid fermentation from Escherichia coli. Biochemistry 68(11): $1159-1170$

Beriault R, Chenier D, Singh R, Middaugh J, Mailloux R, Appanna VD (2005) Detection and purification of glucose 6-phosphate dehydrogenase, malic enzyme, and NADPdependent isocitrate dehydrogenase by blue native polyacrylamide gel electrophoresis. Electrophoresis 26(15): 2892-2897

Beriault R, Hamel R, Chenier D, Mailloux RJ, Joly H, Appanna VD (2007) The overexpression of NADPH-producing enzymes counters the oxidative stress evoked by gallium, an iron mimetic. Biometals 20(2): 165-176

Bignucolo A, Appanna VP, Thomas SC, Auger C, Han S, Omri A et al. (2013) Hydrogen peroxide stress provokes a metabolic reprogramming in Pseudomonas fluorescens enhanced production of pyruvate. J Biotechnol 167:309-15

Bradford MM (1976) A rapid and sensitive method for the quantitation of microgram 
quantities of protein utilizing the principle of protein-dye binding. Anal Biochem 72:24854

Brioukhanov, AL, Netrousov AI, Eggen RIL (2006) The catalase and superoxide dismutase genes are transcriptionally up-regulated upon oxidative stress in the strictly anaerobic archaeon Methanosarcina barkeri. Microbiology 152:1671-1677

Chenier D, Beriault R, Mailloux R, Baguie M, Abramia G, Lemire J, (2008) Involvement of fumarase $\mathrm{C}$ and $\mathrm{NADH}$ oxidase in metabolic adaptation of Pseudomonas fluorescens cells evoked by aluminum and gallium toxicity. Appl Environ Microbiol 74(13): 39773984

Gul-Karaguler N, Sessions RB, Clarke AR, Holbrook JJ (2001) A single mutation in the NAD-specific formate dehydrogenase from Candida methylica allows the enzyme to use NADP. Biotechnol Lett 23:283-287

Hamel R, Appanna VD, Viswanatha T, Puiseux-Dao S (2004) Overexpression of isocitrate lyase is an important strategy in the survival of Pseudomonas fluorescens exposed to aluminum. Biochem Biophys Res Commun 217:1189-94

Hoelsch K, Suhrer I, Heusel M, Weister-Botz D (2013) Engineering of formate dehydrogenase: synergistic effect of mutations affecting cofactor specificity and chemical stability. Appl Microbiol Biotechnol 97(6):2473-81

Hourton-Cabassa C, Ambard-Bretteville F, Moreau F, Davy de Virville J, Remy R, Colas 
des Franc-Small C (1998) Stress induction of mitochondrial formate dehydrogenase in potato leaves. Plant Physiol 116(2):627-635

Jormakka M, Tornroth S, Byrne B, Iwata S (2002) Molecular basis of proton motive force generation: Structure of formate dehydrogenase-N. Science 295(5561): 1863-1868

Jormakka M, Byrne B, Iwata S (2003) Formate dehydrogenase - a versatile enzyme in changing environments. Curr Opin Struct Biol 13(4): 418-423

Lemire J, Appanna VD (2011) Aluminum toxicity and astrocyte dysfunction: A metabolic link to neurological disorders. J Inorg Biochem 105(11):1513-1517

Leonharsberger S, Korsa I, Bock A (2002) The molecular biology of formate metabolism in Enterobacteria. J Mol Micorbiol Biotechnol 4(3): 269-276

Li S, Liu H, Zhang Y, Yan Y, Li Y (2009) The protective effects of $\alpha$-ketoacids against oxidative stress on rat spermatozoa in vitro. Asian J Androl 12(2):247-256

Mailloux RJ, Puiseux-Dao S, Appanaa VD (2009) $\alpha$-ketoglutarate abrogates the nuclear localization of HIF-1 $\alpha$ in aluminum-exposed hepatocytes. Biochimie 91:408-415

Mailloux RJ, Lemire J, Appanna VD (2010) Metabolic networks to combat oxidative stress in Pseudomonas fluorescens. A van Leeuw J Microb 99(3): 433-442

Mailloux RJ, Beriault R, Lemire J, Singh R, Chenier DR, et al (2007) The Tricarboxylic Acid Cycle, an Ancient Metabolic Network with a Novel Twist. PLoS One 2(8): e690. Mailloux RJ, Lemire J, Kalyuzhnyi S, Appanna VD (2008) A novel metabolic network 
leads to enhanced citrate biogenesis in Pseudomonas fluorescens exposed to aluminum toxicity. Extremophiles 12:451-459

Schagger H, von Jagow G (1991) Blue native electrophoresis for isolation of membrane protein complexes in enzymatically active form. Anal Biochem 199(2): 223-31

Shinagawa E, Toyama H, Matsushita K, Tuitemwong P, Theeragool G, Adachi O (2008)

Formaldehyde elimination with formaldehyde and formate oxidase in membrane of acetic acid bacteria. J Biosci Bioeng 105(3): 292-295

Singh R, Lemire J, Mailloux RJ, Appanna VD (2008) A novel strategy involved antioxidative defense: the conversion of NADH into NADPH by a metabolic network. PloS One 3:2682

Stubbe J, Nocera DG, Yee CS, Chang MCY (2003) Radical initiation in the class I ribonucleotide reductase: Long-range proton-coupled electron transfer? Chem Rev 103(6):2167-2202

Su C, Puls RW (2004) Nitrate reduction by zero valent iron: Effects of formate, oxalate, citrate, chloride, sulfate, borate, and phosphate. Environ Sci Technol 38(9): 2715-2720

Suzuki K, Itai R, Suzuki K, Nakanishi H, Nishizawa N, Yoshimura E, Mori S (1998) Formate dehydrogenase, an enzyme of anaerobic metabolism, is induced by iron deficiency in Barley Roots. Plant Physiol 116(2):725-732

Thomas SC, Alhasawi A, Appanna VP, Auger C, Appanna VD (2015) Brain metabolism 
and Alzheimer's disease the prospect for a metabolite-based therapy. J Nutr Health Aging 19(1):58-63

Uchimura H, Enjoji H, Seki T, Taguchi A, Tsakaya N, Shoun H (2002) Nitrate reductaseformate dehydrogenase couple involved in the fungal denitrification by Fusarium oxysporum. J Biochem 131(4): 579-586

Yammamoto I, Saiki T, Liu SM, Ljungdahl LG (1983) Purification and properties of NADP-dependent formate dehydrogenase from Clostridium thermoaceticum a tungstenselenium-iron protein. J Biol Chem 258(3): 1826-32

Ying W (2008) NAD/NADH and NADP/NADPH in cellular functions and cell death: regulation and biological consequences. Antioxid Redox Signal 10:179-206

Yokota A, Kawabata A, Kitaoka S (1983) Mechanism of glyoxylate decarboxylation in the glycolate pathway in Euglena gracilis $Z$ participation of $\mathrm{Mn}^{2+}$-dependent NADPH oxidase in chloroplasts. Plant Physiol 71: 772-776

Yokota A, Koura H, Kitaoka S (1985) Refixation of photorespired $\mathrm{CO}_{2}$ during photosynthesis in Euglena gracilis Z. Agric Biol Chem 49:3309-10

Yoshida A, Nishimura T, Kawaguchi H, Inui M, Yukawa H (2005) Enhanced hydrogen production from formic acid by formate hydrogen lyase-overexpressing Escherichia coli strains. Appl Environ Microbiol 71(11): 6762-6768

Zaunmuller T, Kelly DJ, Glockner FO, Unden G (2006) Succinate dehydrogenase 
functioning by a reverse redox loop mechanism and fumarate reductase in sulphatereducing bacteria. Microbiology 152: 2443-2453 
2.6 Figures, legends and table

A

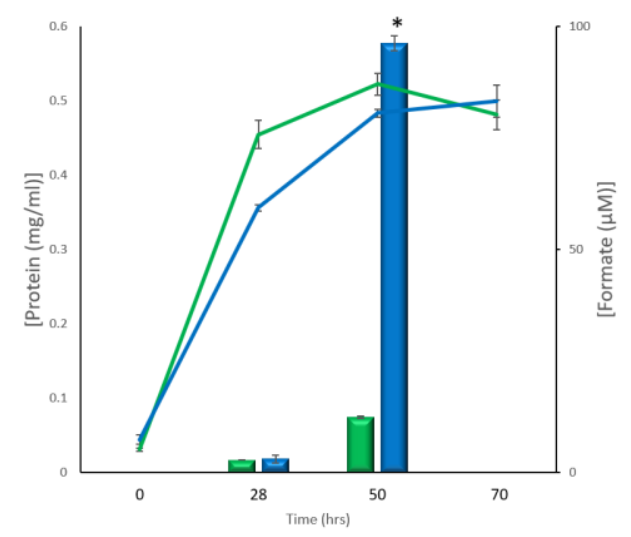

B

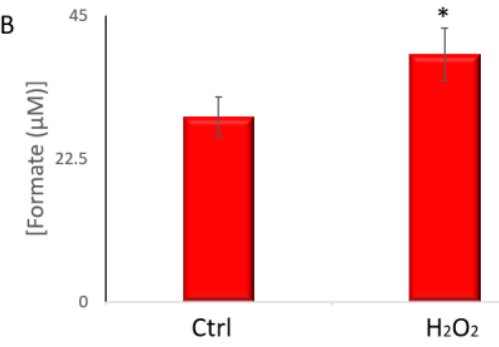

C

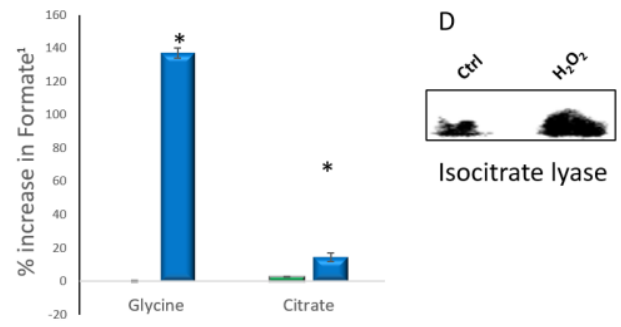

Figure 2.1: Formate production in P. fluorescens (A.) Bacterial cell growth as measured by the Bradford assay (protein $(\mathrm{mg} / \mathrm{ml}$ of culture) and formate production (monitored (by

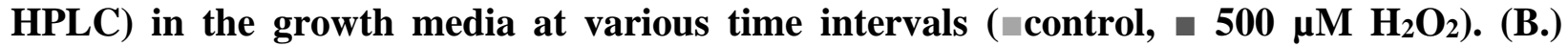
Formate levels within the soluble cell free extract (CFE). (C.) Percent increase in formate in a whole cell experiment in which cells were taken at stationary phase from control \& $500 \mu M$ $\mathrm{H}_{2} \mathrm{O}_{2}$ (stress) and re-suspended in control and stress media (_control, $\_500 \mu \mathrm{M} \mathrm{H}_{2} \mathrm{O}_{2}$ ) containing only the carbon source (citrate) and nitrogen source (glycine) for 8 hours respectively ${ }^{1}$. (D.) In-gel activity of isocitrate lyase from soluble CFE obtained from control and $500 \mu \mathrm{M} \mathrm{H}_{2} \mathrm{O}_{2}$ culture at the same growth phase. Gels are representative of at least 3 independent trials. *represents statistical significance in comparison to control; $n=3, p<0.05$, mean \pm S.D.

\footnotetext{
1 These values were compared to the formate levels in the control experiments where the cells were omitted respectively.
} 

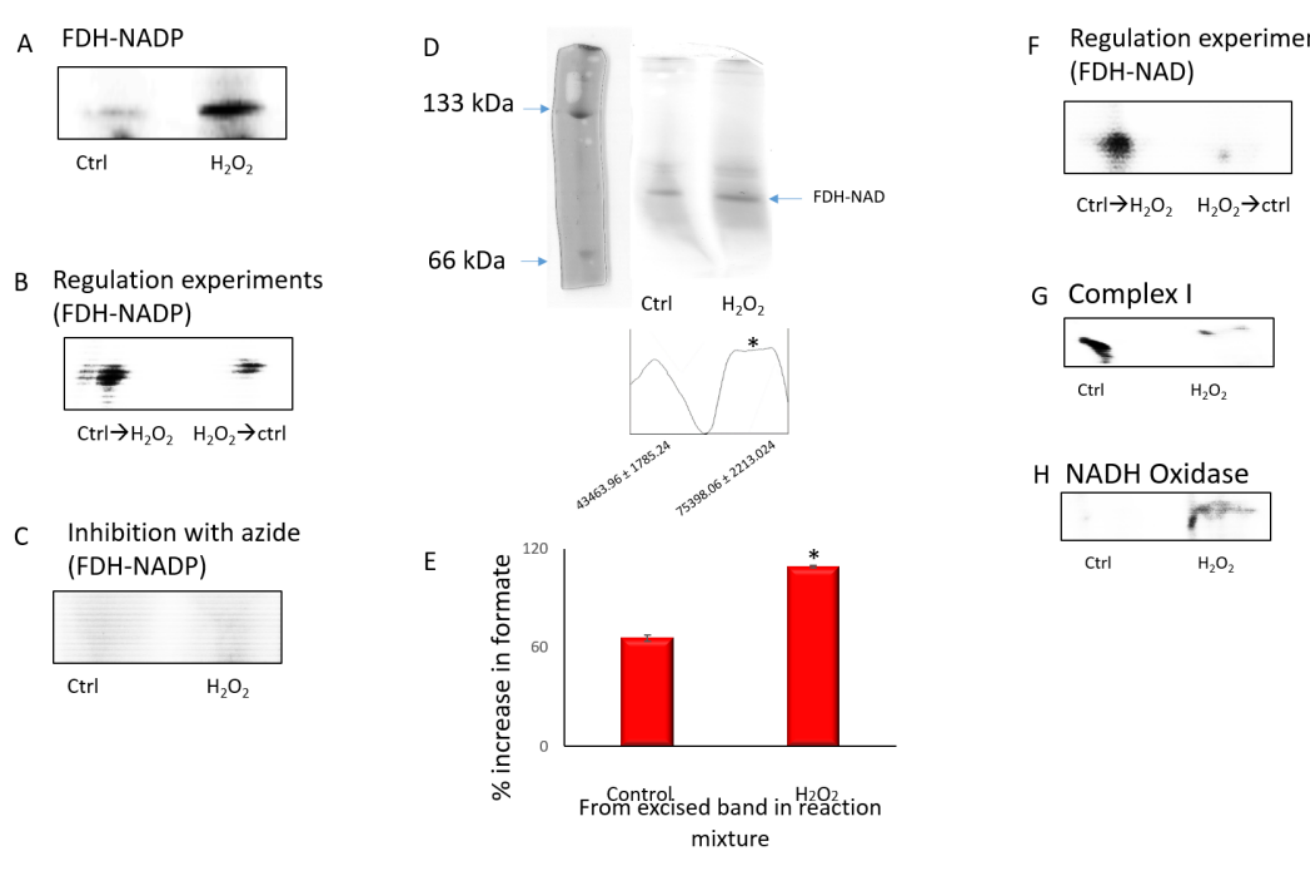

Figure 2.2: NADH homeostasis under oxidative stress. (A.) In-gel activity of FDH-NADP. (B.) In-gel activity of FDH-NADP following regulation experiments. (C.) In-gel activity of FDH-NADP using azide inhibitor to ensure specificity of enzyme. (D.) In-gel activity of NADdependent formate dehydrogenase. (E.) Percent increase in formate production from incubation of excised activity bands of FDH-NAD following BN-PAGE, for 30 minutes in reaction mixture containing $0.5 \mathrm{mM} \mathrm{NADH}$ and $5 \mathrm{mM}$ bicarbonate ${ }^{2}$. (F.) In-gel activity of FDH-NAD following regulation experiments. (G.) In-gel activity of complex I. (H.) In-gel activity of NADH oxidase between control and stress cells. Gels are representative of at least 3 independent trials. *represents statistical significance in comparison to control; $n=3$, p<0.05, mean \pm S.D.

\footnotetext{
${ }^{2}$ These are compared to the formate values in the reaction mixture in the control and stressed bands at time 0.
} 
A
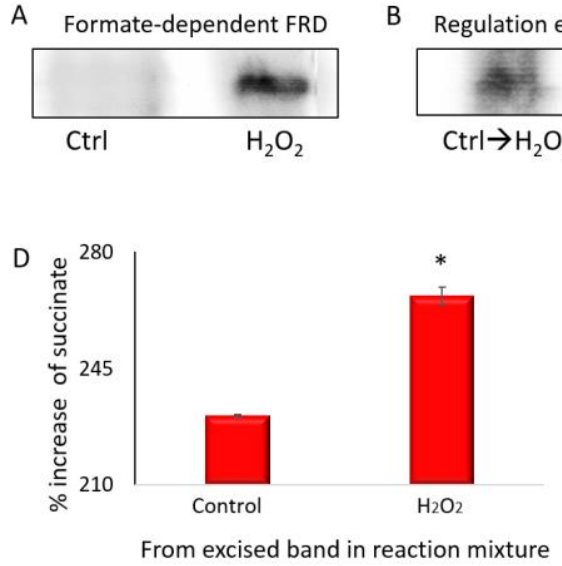

Regulation experiments - FRD

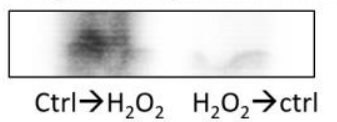

C NAD-dependent FRD

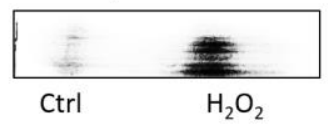

E

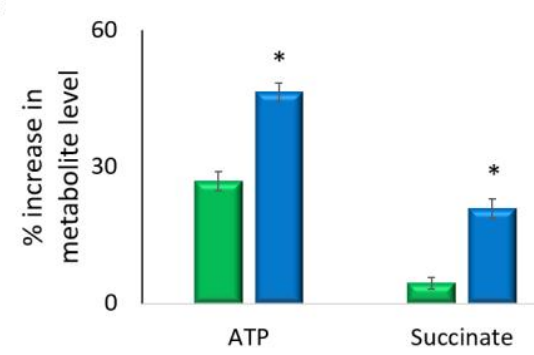

Figure 2.3: Formate-dependent succinate production. (A.) In-gel activity of formatedependent fumarate reductase (FRD). (B.) In-gel activity of formate-dependent fumarate reductase following regulation experiments. (C.) In-gel activity of NAD-dependent fumarate reductase. (D.) Percent increase in succinate production from excised bands following BNPAGE incubated for 30 minutes in reaction mixture containing $5 \mathrm{mM}$ fumarate and $0.5 \mathrm{mM}$ formate $^{3}$. (E.) Percent increase in metabolites (ATP and succinate) from an HPLC reaction containing Pseudomonas fluorescens membrane fraction incubated in reaction buffer with 2 $\mathrm{mM}$ fumarate, $0.5 \mathrm{mM}$ formate and $0.5 \mathrm{mM}$ ADP for 30 minutes (_control, $500 \mu \mathrm{M}$ $\mathrm{H}_{2} \mathrm{O}_{2}$ ). Gels are representative of at least 3 independent trials. *represents statistical significance in comparison to control; $n=3, p<0.05$, mean \pm S.D.

\footnotetext{
${ }^{3}$ These are relative to succinate levels in the control and stress reaction bands at time 0 respectively.
} 


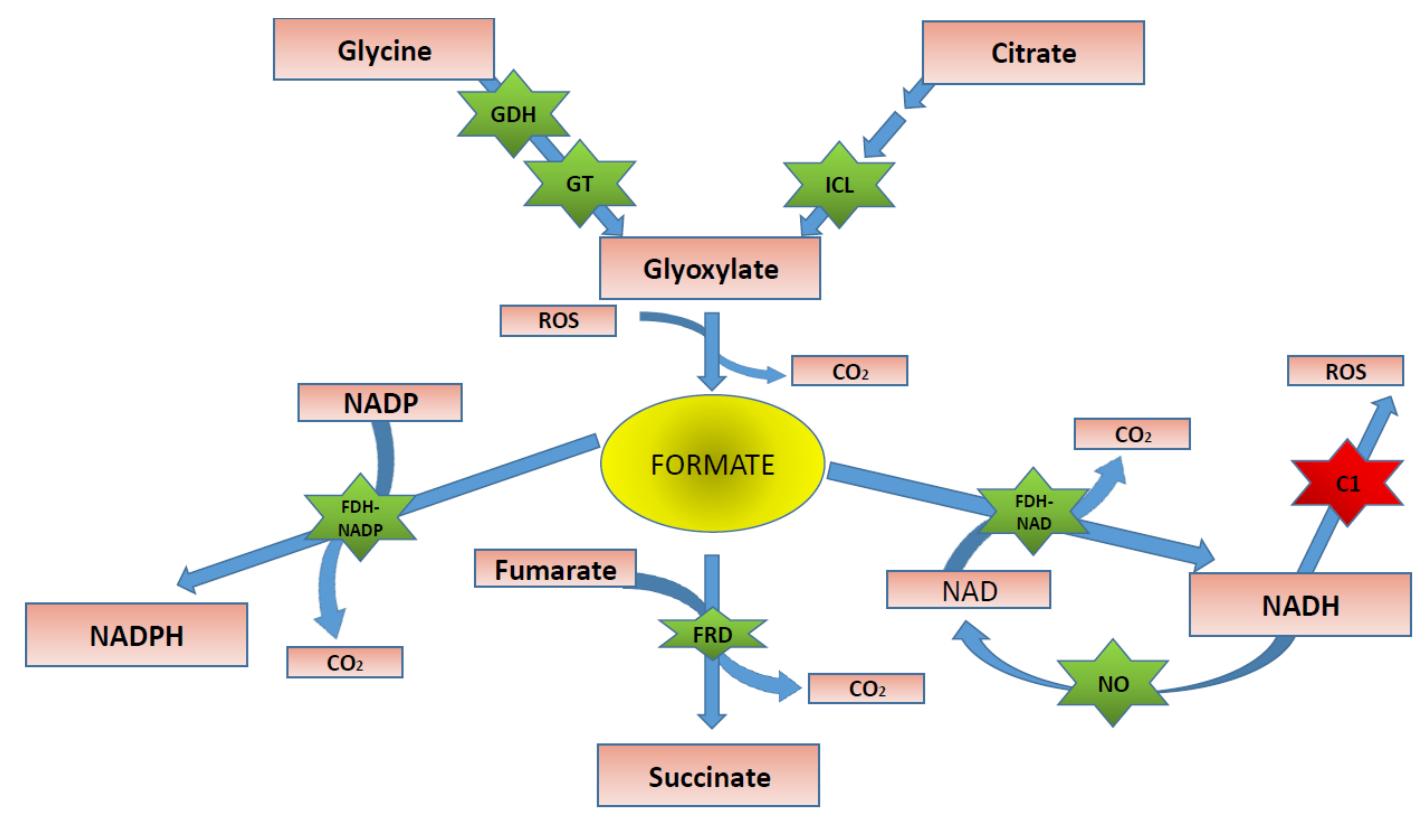

Figure 2.4: Schematic demonstrating the metabolic shift involving the role of formate in $P$. fluorescens in combatting oxidative stress (GDH: Glycine dehydrogenase; GT: Glycine transaminase; ICL: isocitrate lyase; FDH-NADP: NADP-dependent formate dehydrogenase; FRD: Fumarate reductase-formate dependent; FDH-NAD: NAD-dependent formate dehydrogenase; NO: NADH oxidase; C1: Complex I). $\star \star \star \gamma=$ increase in enzyme activity $\widehat{t}=$ decrease in enzyme activity. 
Table 1. Monitoring the activity of the select enzymes using spectrophotometric assays.

\begin{tabular}{lll}
\hline & Control & $500 \mu \mathrm{mol} \mathrm{H}_{2} \mathrm{O}_{2}$ \\
\hline $\mathrm{ME}$ & $2.42 \pm .59$ & $4.29 \pm 1.47$ \\
$\mathrm{ICDH}-\mathrm{NADP}$ & $1.38 \pm .88$ & $2.63 \pm .29$ \\
$\mathrm{ICDH}-\mathrm{NAD}$ & $1.13 \pm .27$ & $.57 \pm .09 *$ \\
$\mathrm{MDH}$ & $1.78 \pm .08$ & $1.33 \pm .13 *$ \\
\hline
\end{tabular}

$\mu$ mol NAD(P)H produced min-1 mg protein-1 as monitored at 340nm ( $\mathrm{n}=3 \pm$ standard deviation). *represents statistical significance in comparison to control; $\mathbf{n}=3$, p<0.05, mean \pm S.D.

$$
\mathrm{ME}=\text { malic enzyme, ICDH-NAD= NAD dependent isocitrate }
$$

dehydrogenase, ICDH-NADP= NADP dependent isocitrate dehydrogenase, $\mathrm{MDH}=$ malate dehydrogenase). 
CHAPTER 3: Conclusion, Future Research and General bibliography 


\subsection{Conclusion}

The results from this project unveil that $P$. fluorescens grown in citrate media with glycine as the sole nitrogen source was able to thrive in spite of the negative impact of oxidative stress. In addition to modifying its metabolism to promote the formation of glyoxylate which results in increased formate production, the microbe is then able to utilize the formate in a multi-pronged antioxidative defense mechanism that promotes NADPH production, and ATP formation. This monocarboxylic acid is also invoked as a source for reducing power that is involved in a variety of enzymatic reactions thus, obviating the need for NADPH and NADH. The latter is a pro-oxidant and its diminished synthesis would aid in impeding intracellular ROS formation.

FDH-NADP, which was markedly increased in the stressed cells might help with the increase of NADPH which is a critical component of the antioxidative defense mechanisms in these organisms (Beriault et al., 2005, Beriault et al., 2007). Additionally, enzymes like ME and ICDH NADP also displayed enhanced activity in the stressed cells, an observation that is indicative of the importance in NADPH in antioxidative defense strategies.

NADH producing enzymes such as ICDH-NAD and MDH were found to be diminished in the stressed cells consistent with previous studies (Alhasawi et al., 2015). However, the activity of FDH-NAD was in fact found to be augmented in the stressed cells. It is postulated that the added NADH would prove beneficial in the reduction of fumarate to succinate via FRD which was also found to be up-regulated. However, it is evident that the organism has opted for enhanced 
production of NADPH and diminished formation of NADH. This metabolic reprogramming not only helps combat oxidative stress via NADPH but also limits the intracellular generation of ROS through the activity of the pro-oxidant, NADH. The diminished NADH synthesis appears to be compensated by the utilization of formate as a reducing co-factor. Enzyme like fumarate reductase readily converts fumarate into succinate in the presence of formate. Thus, formate produced seemingly as a byproduct of ROS detoxification with the non-enzymatic decarboxylation of glyoxylate may in fact contribute to the antioxidative defense mechanism via the generation of $\mathrm{NADPH}$ but also acts as a potent reductive force generating key metabolites to enhance the viability of the bacteria. This study revealed the significance of metabolic reprogramming in antioxidative defense and demonstrated the critical role keto-acids play in diminishing oxygen tension.

\subsection{Future work}

Future work emanating from these findings can be aimed at examining formate homeostasis in cellular systems exposed to oxidative stress. This study may be accomplished via the use of labelled citrate or labelled glycine in separate experiment to delineate which of these carbon sources contributes to the maximal formation of formate. Additionally, the participation of formate as reducing factor in various enzymes like ribonucleotide reductase can also explored. Arguably alternate pathways leading to formate synthesis under stressed condition can also be

evaluated. Formate is being used to make energy as well as a substitute of NADH/NADPH. Other 
enzymes such as ribonucleotide reductases which could potentially utilize formate in lieu of NADH/NADPH to drive metabolism can be studied.

Furthermore preliminary data show that formate may also play a role in the detoxification of nitrosative stress. Indeed, $\mathrm{NO}_{2} / \mathrm{NO}_{3}$ reductases were found to have elevated activity in cells stressed with sodium nitroprusside (SNP), a generator of reactive oxy-nitrosative species (RONS). Future studies can also be devoted to the mechanisms by which this microbe combats reactive nitrogen species (RNS) and also to delineate whether or not formate is being used in the energymaking machinery and contributing to the NADH/NADPH balance. This will help establish a universal role of formate in neutralizing oxidative stress, especially in the light of the recent findings that correlate the levels of this monocarboxylic acid in blood to hypertension in humans (Holmes et al., 2008). 


\subsection{General Bibliography}

Alhasawi A, Castonguay Z, Appanna ND, Auger C, Appanna VD (2015) Glycine metabolism and antioxidative defense mechanisms in Pseudomonas fluorescens. Microbiol Res 171: 26-31

Auger C, Han S, Appanna VP, Thomas SC, Ulibarri G, Appanna VD (2012) Metabolic reengineering invoked by microbial systems to decontaminate aluminum: Implications for bioremediation technologies. Biotechnol Adv 30: 142-153

Beriault R, Chenier D, Singh R, Middaugh J, Mailloux R, Appanna VD (2005) Detection and purification of glucose 6-phosphate dehydrogenase, malic enzyme, and NADPdependent isocitrate dehydrogenase by blue native polyacrylamide gel electrophoresis. Electrophoresis 26(15): 2892-2897

Beriault R, Hamel R, Chenier D, Mailloux RJ, Joly H, Appanna VD (2007) The overexpression of NADPH-producing enzymes counters the oxidative stress evoked by gallium, an iron mimetic. Biometals 20(2): 165-176

Bignucolo A, Appanna VP, Thomas SC, Auger C, Han S, Omri A, Appanna VD (2013) Hydrogen peroxide stress provokes a metabolic reprogramming in Pseudomonas fluorescens: Enhanced production of pyruvate. J Biotechnol 167: 309-315

Cadenas E, Davies KJA (2000) Mitochondrial free radical generation, oxidative stress and aging. Free Radical Bio Med 29(3-4): 222-230

D'Autreaux B, Toledano MB (2007) ROS as signaling molecules: mechanisms that 
generate specificity in ROS homeostasis. Nat Rev Mol Cell Bio 8: 813-824

Dubbs JM, Mongkolsuk S (2007) Peroxiredoxins in bacterial antioxidant defense.

Peroxiredoxin systems, Chapter 6: 143-193, Springer.

Espinoza SE, Guo H, Fedarko N, DeZern A, Fried LP, Xue Q, Leng S, Beamer B, Walston

JD (2010) Glutathione peroxidase enzyme activity in aging. J Gerontol A Biol Sci Med Sci 63(5): 505-509

Grune T, Schroder P, Biesalski HK (2005) Low molecular weight antioxidants. The Handbook of Environmental Chemistry. 2:77-90

Holmes E, Loo RL, Stamler J, Bictash M, Yap IKS, Chan Q, Ebbels T, Iorio MD, Brown IJ, Veselkov KA, Daviglus ML, Kesteloot H, Ueshima H, Zhao L, Nicholson JK, Elliott P (2008) Human metabolic phenotype diversity and its association with diet and blood pressure. Nature 453: 396-400

Imlay JA (2009) Oxidative stress. In EcoSal-Escherichia Coli and Salmonella: Cellular and Molecular Biology, Chapter 5.4.4. Böck A, Curtiss R III Kaper JB, Karp PD, Neidhardt FC, Nystrom T, et al. (eds). Washington, DC: ASM Press

Kirkman HN, Gaetani GF (2006) Mammalian catalase: a venerable enzyme with new mysteries. Trends Biochem Sci 32(1): 44-50

Kohen R, Nyska A (2002) Oxidation of biological systems: oxidative stress phenomena, antioxidants, redox reactions, and methods for their quantification. Toxicol Pathol 30(6): $620-650$ 
Lemire J, Milandu Y, Auger C, Bignucolo A, Appanna VP, Appanna VD (2010) Histidine is a source of the antioxidant alpha-ketoglutarate in Pseudomonas fluorescens challenged by oxidative stress. FEMS Microbiol Lett 309: 170-177

Lemire J, Mailloux R., Auger C, Whalen D, Appanna VD (2011) Pseudomonas fluorescens orchestrates a fine metabolic-balancing act to counter aluminum toxicity (mini-review). Environ Microbiol 12: 1384-1390

Leonhartsberger S Korsa I, Bock A (2002) The molecular biology of formate metabolism in enterobacteria. J Mol Microbiol Biotechnol 4: 269-276

Lombard M, Fontecave M, Touati D, Niviere V (2000) Reaction of the desulfoferrodoxin from Desulfoarculuis baarsii with superoxide anion. Evidence for a superoxide reductase activity. J Biol Chem 275: 115-121

Lushchak VI (2001) Oxidative stress and mechanisms of protection against it in bacteria. Biochemistry 66(5): 476-489

Mailloux RJ, Hamel R, Appanna VD (2006) Aluminum toxicity elicits a dysfunctional TCA cycle and succinate accumulation J Biochem Mol Toxic 20:198-208

Mailloux RJ, Lemire J, Appanna VD (2010) Metabolic networks to combat oxidative stress in Pseudomonas fluorescens. A van Leeuw J Microb 99(3): 433-442

Niviere V, Fontecave M (2004) Discovery of superoxide reductase: an historical Perspective. J Biol Inorg Chem 9:119-123

O’Sullivan DJ, O'Gara F (1992) Traits of fluorescent Pseudomonas spp. involved in 
suppression of plant root pathogens. Microbiol Rev 56: 662-676

Paulsen IT, Press CM, Ravel J, Kobayashi DY, Myers GS, Mavrodi DV, DeBoy RT, Seshadri R, Ren Q, Madupu R, Dodson RJ, Durkin AS, Brinkac LM, Daugherty SC, Sullivan SA, Rosovitz MJ, Gwinn ML, Zhou L, Schneider DJ, Cartinhour SW, Nelson WC, Weidman J, Watkins K, Tran K, Khouri H, Pierson EA, Pierson LS 3rd, Thomashow LS, Loper JE (2005) Complete genome sequence of the plant commensal Pseudomonas fluorescens Pf-5. Nat Biotechnol 23: 873-878

Poole LB (2003) Bacterial peroxiredoxins signal transduction by reactive oxygen and nitrogen species: pathways and chemical principles. Springer. Chapter 5: 80-101

Ralser M, Wamelink MMC, Latkolik S, Jansen EEW, Lehrach H, Jakobs C (2009) Metabolic reconfiguration precedes transcriptional regulation in the antioxidant response. Nat Biotechnol 27: 604-605

Rodgers AJW, Wilce MCJ (2000) Structure of the gamma to epsilon complex of ATP synthase. Nat Struct Biol 7: 1051-1054.

Shao H, Chu L, Lu Z, Kang C (2008) Primary antioxidant free radical scavenging and redox signaling pathways in higher plant cells. Int J Biol Sci 4: 8-14

Sies H (1997) Oxidative stress: oxidants and anti-oxidants. Exp Physiol 82: 291-295

Singh R, Mailloux R, Puiseux-Dao S, Appanna VD (2007) Oxidative stress evokes a 
metabolic adaptation that favours increased NADPH synthesis and decreased NADH production in Pseudomonas fluorescens. J Bacteriol 189: 6665-6675

Singh R, Lemire J, Mailloux R, Appanna VD (2008) A novel strategy involved in antioxidative defense: the conversion of NADH into NADPH by a metabolic network. PLoS One 3(7): e2682

Slauch JM (2011) How does the oxidative burst of macrophages kill bacteria? Still an open question. Mol Microbiol 80(3): 580-583

Ursini F, Maiorino M, Brigelius-Flohe R, Aumann KD, Roveri A, Schomburg D, Flohe L (1995) Diversity of glutathione peroxidases. Method Enzymol 252: 38-53

Wang G, Alamuri P, Maier RJ (2006) The diverse antioxidant systems of Helicobacter pylori. Mol Microbiol 61(4): 847-860 


\section{Publications and Communications}

Alhasawi A, Thomas SC, Appanna VD (2016). Metabolic networks to generate pyruvate pep and ATP from glycerol in Pseudomonas fluorescens. Enzyme Microb Tech (In press)

Thomas SC, Alhasawi A, Auger C, Omri A, Appanna VD (2015). The role of formate in combatting oxidative stress. A van Leeuw J Microb 109(2): 263-271 (Part of my thesis work)

Castonguay Z, Auger C, Thomas SC, Chahma M, Appanna VD (2014). Nuclear lactate dehydrogenase modulated histone modification in human hepatocytes. Biochem Biophys Res Commun 454 (1): 173-7

Appanna VP, Auger C, Thomas SC, Omri A (2014). Fumarate metabolism and ATP production in Pseudomonas fluorescens exposed to nitrosative stress. A van Leeuw $\mathbf{J}$ Microb 106 (3): 431-438

Thomas SC, Alhasawi A, Appanna VP, Auger C, Appanna VD (2014). Brain metabolism and Alzheimer's disease: The prospect of a metabolite-based therapy. J Nutr Health Aging 19 (1): 58-63.

Han S, Auger C, Thomas SC, Beites CL, Appanna VD (2013). Mitochondrial biogenesis 
and energy production in differentiating stem cells: A functional metabolic study. Cell Reprogram 16(1): 84-90

Bignucolo A, Appanna VP, Thomas SC, Auger C, Han S, Omri A, Appanna VD (2013).

Hydrogen peroxide stress provokes a metabolic reprogramming in P. fluorescens: Enhanced production of pyruvate. J Biotechnol 167: 309-315

Auger C, Han S, Appanna VP, Thomas SC, Ulibarri G, Appanna VD (2012). Metabolic reengineering invoked by microbial systems to decontaminate aluminum: Implications for bioremediation technologies. Biotechnol Adv 31: 266-273

Han S, Auger C, Castonguay Z, Appanna VP, Thomas SC, Appanna VD (2012). The unraveling of metabolic dysfunctions linked to metal-associated diseases by blue native polyacrylamide gel electrophoresis. Anal Bioanal Chem 406(6): 1821-31

Dudar K, Thomas SC, Chamberland J, Ferguson R, Dickinson J (2014). Visual verbs versus visual verbs: A study of within-list variability. Poster presented at the Canadian Society of Brain, Behaviour and Cognitive Science (CSBBCS) conference, Toronto, ON.

Thomas SC, Cirelli LK, Dickinson J (2013). Distinguishing between 'sense' and 'notice':

Performing various perceptual actions elicits differentiable P300 responses. Poster presented at Psychonomics conference, Toronto, Ontario. 
Thomas SC, Chamberland J, Labbe AP, Roy-Charland A, Perron M (2013). Impact of instructions in the judgment of authenticity of smiles. Poster presented at the CSBBCS conference, Calgary, AB.

Dudar KJ, Thomas SC, Elliott RL, Dickinson J (2013). Mental action verb processing: an ERP investigation. Poster presented at CSBBCS, Calgary, AB.

Thomas SC, Dickinson J (2013). Mental action verb processing: An ERP investigation. Represented Laurentian with a Three Minute Thesis presented at the Ontario 3MT competition, Kingston, ON.

Dickinson J, Roy-Charland A, Perron M, Thomas SC, Beaudry O (2012) The Confusion Between Fear and Surprise: An ERP Investigation of The Perceptual Limitation Hypothesis., Poster presented at Psychonomics conference, Minneapolis, Minnesota.

Thomas SC, Brothers T, Vares D, Dickinson J. (2012). Verifiability and Action Verb Processing: an ERP investigation. Poster presented at the CSBBCS conference. Kingston, ON.

Thomas SC, Appanna VD (2012). Ketoacids as antioxidants in human astrocytes exposed 
to oxidative and aluminum stress. Oral presentation at the Southern Ontario Undergraduate Chemistry Conference (SOUSCC), Biological Life Sciences division, Guelph, ON. 